\title{
Diversity, Function and Regulation of Cell Surface and Intracellular Immune Receptors in Solanaceae
}

\author{
Jong Hum Kim ${ }^{1,2, *}$ and Christian Danve M. Castroverde ${ }^{3, *(\mathbb{D}}$ \\ 1 Department of Energy Plant Research Laboratory, Michigan State University, East Lansing, MI 48824, USA \\ 2 Howard Hughes Medical Institute, Michigan State University, East Lansing, MI 48824, USA \\ 3 Department of Biology, Wilfrid Laurier University, Waterloo, ON N2L 3C5, Canada \\ * Correspondence: kimjun73@msu.edu (J.H.K.); dcastroverde@wlu.ca (C.D.M.C.)
}

Received: 26 February 2020; Accepted: 23 March 2020; Published: 1 April 2020

\begin{abstract}
The first layer of the plant immune system comprises plasma membrane-localized receptor proteins and intracellular receptors of the nucleotide-binding leucine-rich repeat protein superfamily. Together, these immune receptors act as a network of surveillance machines in recognizing extracellular and intracellular pathogen invasion-derived molecules, ranging from conserved structural epitopes to virulence-promoting effectors. Successful pathogen recognition leads to physiological and molecular changes in the host plants, which are critical for counteracting and defending against biotic attack. A breadth of significant insights and conceptual advances have been derived from decades of research in various model plant species regarding the structural complexity, functional diversity, and regulatory mechanisms of these plant immune receptors. In this article, we review the current state-of-the-art of how these host surveillance proteins function and how they are regulated. We will focus on the latest progress made in plant species belonging to the Solanaceae family, because of their tremendous importance as model organisms and agriculturally valuable crops.
\end{abstract}

Keywords: plant immunity; solanaceous plants; pattern recognition receptor; NB-LRR receptor; resistance protein; immune receptor; host-pathogen interaction

\section{Introduction}

Solanaceae, a family of flowering dicot plants including valuable crops such as tomato, potato, and pepper, have been studied for a long time because of their agricultural and economic importance. Because these plants are targeted by various pathogens, the insights on plant-pathogen interactions are important to maintain these plants' agronomic value [1]. Research for the past several decades have demonstrated that pathogens and plants have been co-evolving through continuous pressure for survival. Pathogens have effective and versatile weapons to conquer their host, while hosts also have diverse shields and sensors to avoid and detect invasions by pathogens [2].

As a first layer of the plant innate immune system, receptors have been adopted and developed to sense invaders. In the apoplast where the plant plasma membrane is the first venue encountered by pathogen invasion, it proves effective for plants to localize diverse receptors at this front line. These receptors usually detect highly conserved molecules, such as small peptides and carbohydrates, found in a group of microorganisms. These invasion patterns or ligands are typically microbe- or pathogen-associated molecular patterns (MAMPs/PAMPs) and the resulting immune response is called pattern-triggered immunity (PTI). Downstream PTI responses include production of reactive oxygen species, alterations in plant cell wall, and induction of antimicrobial compounds, which are delicately mediated by complex signal transduction pathways [3].

In contrast to pattern-triggered immunity, host resistance $(R)$ proteins of the nucleotide-binding leucine-rich receptor (NLR) family are specialized intracellular receptors for gene-for-gene immunity. 
These NLRs target matching avirulence (Avr) factors in a pathogen [2]. To enhance their fitness in plant tissues, pathogens have adopted molecular tools which are secreted to the extracellular matrix or into the plant cell. Since effector proteins from Avr genes secreted into the plant cell can suppress the plant immune system, host receptors for these foreign molecules are usually located in the intracellular space [2]. Because these Avr factors tend to be virulence effectors that can shut down certain aspects of plant innate immunity, this NLR-activated response is collectively termed effector-triggered immunity (ETI) [2].

Plant-pathogen interactions occur under dynamically changing environmental conditions, which can modulate plant defense responses in several cases [4]. Therefore, plants have developed diverse mechanisms to find balance and maximize fitness between plant-pathogen interactions and environmental conditions.

In this review, we focus on immune receptors in Solanaceae, especially how they recognize their respective ligands, transduce the signal downstream, and are regulated by external factors.

\section{Cell Surface Immune Receptors in Solanaceous Plants}

\subsection{Structure}

Cell surface immune receptors are typically leucine-rich repeat transmembrane proteins, with their (1) extracellular side responsible for binding and recognizing the ligand or invasion pattern, (2) a transmembrane domain responsible for properly tethering the protein within the plasma membrane, and (3) a cytoplasmic side for downstream signaling. Surface immune receptors can be classified as either receptor-like kinases (RLKs) or receptor-like proteins (RLPs), depending on the presence or absence of kinases activity in their cytoplasmic tail (for extensive review, see Albert et al) [5].

The extracellular domain is used for the perception and binding of molecular patterns that signal impending invasion or danger. As shown in Table 1, the origin and biochemical nature of these invasion patterns are diverse. They could be derived from the invading organism termed microbeor pathogen-associated molecular patterns or MAMPs/PAMPs, or they could be derived from the host itself due to release upon colonization or damage termed damage-associated molecular patterns (DAMPs) [3]. These ligands could be proteinaceous, as in the case of pathogen-derived flagellin epitopes (flg22 and flgII-28) or host-derived systemin [6-8]. They could be carbohydrate-based or lipid-based, as in the case of pathogen-derived chitin and lipopolysaccharide $[9,10]$. Finally, although they have not been demonstrated in solanaceous plants yet, these ligands could also be nucleotide-based, as in the case of pathogen-derived RNAs or host-derived ATP [11,12].

\subsection{Ligand Recognition and Signaling}

Extracellular danger signals or invasion patterns are perceived by supramolecular protein complexes at the plasma membrane, consisting of: (1) The primary ligand-binding immune receptor protein, (2) one or two co-receptors, (3) cytoplasmic kinases, and (4) regulatory proteins. A comprehensive list of solanaceous cell surface immune RLPs and RLKs are outlined in Table 1.

These immune receptors have been shown to either homodimerize or heterodimerize. Homodimerization has been demonstrated during the perception of chitin by Arabidopsis CERK1, which is a member of the LysM family of RLKs [13]. One of the tomato CERK1 homologs is SILYK1, which is involved in chitin-induced responses [9]. Two other tomato CERK1 homologs Bti9 and SILyk13 are known to be targets of the bacterial virulence effector AvrPtoB and play a role in plant immunity [14]. Whether SILYK1, Bti9, and SlLyk13 participate in direct recognition of a certain pathogen-derived ligand through homodimerization has yet to be demonstrated.

Heterodimerization has been shown in several solanaceous cell surface immune receptors. RLKs, like FLS2 (flagellin sensing 2), FLS3 (flagellin sensing 3), and CORE (cold shock protein receptor) tend to form heterodimers with the co-receptor BAK1 after ligand binding $[6,15,16]$. On the other 
hand, because RLPs lack a cytoplasmic kinase domain for downstream immune signaling, they tend to be in a constitutive complex with tomato adaptor kinase SOBIR1 (Suppressor of BIR1-1) [17]. This constitutive immune RLP-adaptor kinase bimolecular complex serves as the functional equivalent of immune RLKs [18]. After ligand binding, the RLP-SOBIR1 complex interacts with BAK1, as shown in various examples like NbCSPR (Receptor-like protein required for csp22 responsiveness) in Nicotiana benthamiana, Cf, Ve, and EIX in tomato, and ELR in potato $[17,19,20]$. Because the ligand for CuRe1 (Cuscuta Receptor 1) has not yet been identified, its interaction with BAK1 has yet to be demonstrated [21].

BAK1 and related co-receptor kinases play a central role not just in plant immunity but in plant growth and development as well [15]. As in the case of FLS2-BAK1, the binding of its ligand flg22 stabilizes the supramolecular protein complex by acting like a molecular adhesive [22]. BAK1 also serves to strengthen and potentiate the phosphorylation events in the immune receptor protein [15]. Solanaceous plant orthologs of BAK1 have been identified. In tomato, SISERK3A and SISERK3B can partially rescue the Arabidopsis bak1 mutant phenotype [23]. In potato, StSERK3A/B mediate defense responses induced by the DAMP Pep-13 [24].

The transmembrane immune receptor-co-receptor complex transduces signals through receptor-like cytoplasmic kinases (RLCKs). One well-characterized RLCK in Arabidopsis is BIK1, for which homologs in solanaceous plants occur. BIK1 is part of the large multigenic RLCK-VII subfamily and participates in the phosphorylation amplification cascade [25]. It is released upon ligand binding from its interaction with the receptor-co-receptor complex [25]. A tomato RLCK called tomato protein kinase $1 \mathrm{~b}(\mathrm{TPK} 1 \mathrm{~b})$ is the BIK1 ortholog as it functionally complements the Arabidopsis bik1 mutant [26]. TPK1b regulates defense responses to necrotrophic pathogens and insects, and has been shown to interact with the PEPR1/2 ORTHOLOG RECEPTOR-LIKE KINASE1 (PORK1) [26]. Although the TPK1b-PORK1 modulates gene expression in response to the wounding hormone systemin, it remains to be seen whether it directly binds the systemin receptor SYR1 or if its effect is due to more indirect means [26]. Also, the tomato Ptila and Ptilb proteins act as RLCKs transducing the immune signals by the invasion pattern flg22 [27]. In pepper, the RLCK CaPIK1 has been shown to be involved in plant defense responses and cell death, but whether it directly interacts with surface receptors has yet to be demonstrated. Deciphering the various molecular substrates of diverse RLCKs are key to identifying the downstream components of RLP/RLK-mediated immune signaling [28].

Signal transduction during cell surface receptor-mediated immunity can be achieved through phosphorylation cascades of MAP kinases and/or calcium-dependent protein kinases (CDPKs). In tomato, genome-wide analyses identified 89 MAPKKK, 5 MAPKK and 13 MAPK genes [29,30]. Also in tomato, genome-wide analyses identified 29 CDPKs and 6 CDPK-related kinases (CRKs), with some involved in basal disease resistance [31]. However, which of these MAPKs and CDPKs directly participate in immune signal transduction have yet to be biochemically demonstrated. Detailed functional and high-throughput analyses in Arabidopsis have shown that these MAPKs and CDPKs could directly phosphorylate transcription factors that translocate to the nucleus to directly regulate immune gene expression [32,33]. Elucidating the various downstream molecular targets of MAPKs and CDPKs in solanaceous plants will broaden our understanding of innate immune signaling and downstream defense gene regulation.

\subsection{Expression and Regulation}

Solanaceous cell surface immune receptors are regulated at multiple levels: (1) Transcriptional and epigenetic, (2) post-transcriptional, and (3) post-translational regulatory mechanisms.

At the transcriptional level, tomato immune receptors have been found to be induced by ergosterol and squalene from the fungal symbiont Trichoderma [34]. In solanaceous plants, examples of RLP/RLK and NLR genes can be induced by wounding [35,36], hormone treatments [10,35,37], pathogen 
infection [10,37-40] and effector gene expression [37,41]. In Arabidopsis, both RLP and NLR genes can be induced by a range of environmental stresses and different hormones [42,43].

Epigenetic regulation has been shown to occur in Arabidopsis. Known immune receptor genes (both cell surface and intracellular) can be affected by epigenetic changes in proximal and distal transposons through trans-regulatory small RNAs dependent on RNA-directed DNA methylation (RdDM) [44]. This is an interesting observation since the tomato Ve1 RLP gene promoter has been shown to possess differential transcriptional activities in its native chromatin context and when it is introduced elsewhere in the genome [37].

Post-transcriptional regulation of cell surface immune receptor mRNAs can occur in various ways, including alternative splicing. In un-induced/uninfected tobacco cells, $N t-S d-R L K$ is produced as a shorter transcript by alternative splicing, where only the extracellular domain is encoded by the mRNA [45]. When the invasion pattern LPS is used to induce the cells, a longer transcript is produced containing the cytoplasmic kinase domain [45]. Because the kinase domain is associated with downstream signaling, this presumably modulates defense responses and maintains immune homeostasis [45].

Finally, post-translational mechanisms of regulation include different processes like differential protein modifications, protein degradation, protein stabilization, protein interaction, and protein trafficking. These regulatory mechanisms allow for proper immune homeostasis and defense signaling in a controlled manner.

In the tomato immune receptor-Ptilb RLCK module [46], a phosphatase termed pattern-triggered immunity inhibiting PP2C 1 (Pic1) negatively controls Ptilb autophosphorylation and activity, which relays flagellin-induced immune signaling [46]. Pti1b autophosphorylation on threonine-233 is abolished when Pic1 is present [46]. An arginine-to-cysteine substitution on residue 240 made Ptilb constitutively active and resistant to Pic1 dephosphorylation, although the Ptilb-Pic1 interaction remained intact [46]. Apart from phosphorylation, immune receptor SUMOylation can modulate its function and downstream immune responses, as in the case of Arabidopsis FLS2 [47], but it has yet to be shown biochemically in solanaceous plants.

Regulation by protein degradation has been demonstrated in the flg22-FLS2-S1PUB13 ubiquitination complex [48]. The tomato homolog of the U-box type E3 ligase PUB13 works with group III E2 enzymes for FLS2 ubiquitination and eventual degradation [48].

Apart from protein degradation, protein stabilization is also key to proper functioning of cell surface immune receptors. Molecular scaffolds, like tomato TFT1 (a 14-3-3) protein, is important in immunity against Xanthomonas and is a target of the Xanthomonas virulence effector XopN [49]. The multifunctional cochaperone Hsp70/90 organizing protein Hop/Sti1 is important for signaling and response to chitin [50].

Differential protein interaction positively or negatively modulates plant immunity. Tomato immune receptor-mediated responses can be negatively regulated by SIBIR3, which interacts with BAK1 [51]. This constitutive BIR3-BAK1 interaction is relieved upon ligand binding, thereby freeing the BAK1 co-receptor to associate with the immune receptor complex [51].

Finally, protein trafficking plays a great role in regulating immune receptor function. SIPRA1A interacts with the tomato EIX receptor and reduces protein levels. In addition, SIPRA1A is presumed to redirect EIX from endosome to the vacuole for degradation [52]. SIPRA1A influences levels of other immune RLPs but not RLKs, suggesting a bifurcation in how these two sets of cell surface receptors are trafficked intracellularly [52]. Endocytosis is regulated by certain protein-protein interaction modules, including those containing the Eps15 homology domain (EHD). In tomato, the EHD2 directly interacts with EIX2 and mediates its internalization and downstream defense outputs [53]. This is specific to RLP as it did not affect the RLK FLS2 (Bar and Avni, 2009). Endocytosis after ligand binding is necessary to replenish new ligand-free receptors, which is known to be mediated by SCD1 and ESCRT1 in Arabidopsis [54,55]. The identification and characterization of solanaceous orthologs of this trafficking components will pave the way for expanding the principles of plant immune signaling and also to relating its crosstalk with other physiological processes. 
Table 1. Known cell surface immune receptors proteins in plant species of the Solanaceae family.

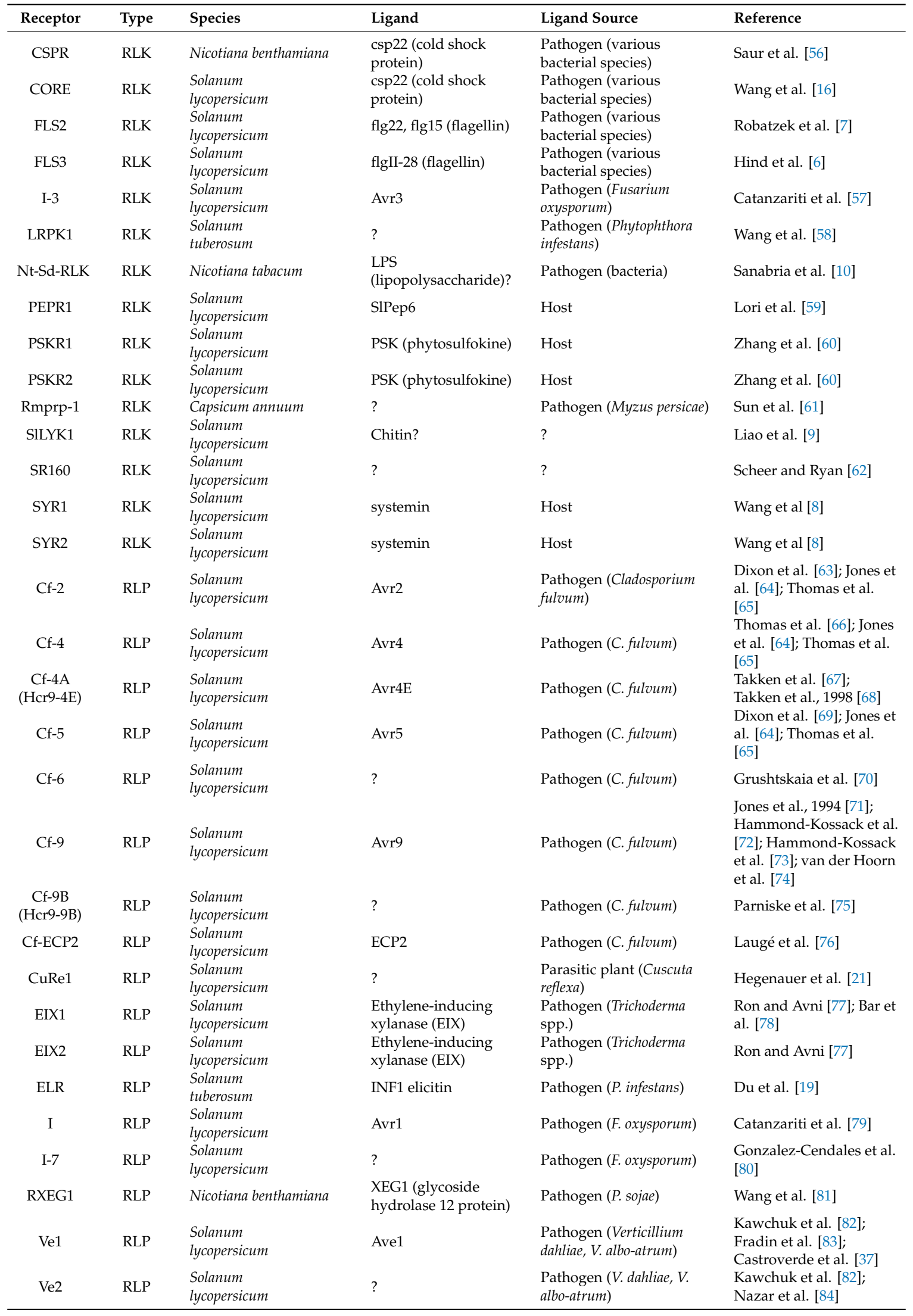




\section{Intracellular Immune Receptors in Solanaceous Plants}

\subsection{Structure}

Intracellular immune receptors that have been studied in Solanaceous plants so far are summarized in Table 2. Although various intracellular immune receptors that bind different ligands from diverse pathogens have been reported, they could be classified by their conserved domains [85]. The nucleotide binding domain (NB-ARC; nucleotide-binding adaptor shared by APAF-1, R proteins, and CED-4) and leucine-rich repeat (LRR) are located in the central and C-terminal regions of these immune receptors [85]. These NB-LRR receptors or NLRs could be divided into TNL (TIR-NB-LRR; Toll/interleukin-1 receptor-nucleotide-binding-leucine-rich repeat) and CNL (CC-NB-LRR; coiled coil-nucleotide-binding-leucine-rich repeat) subgroups by the presence of additional N-terminal domains, TIR domain or CC domain, respectively.

Although the functions of each domain in NLR type receptors are not clear so far, there are delicate studies showing the importance of intramolecular and intermolecular interplay among domains in NLR type receptors. A recent study about the composition and structure of ZAR1 (Arabidopsis NLR protein) revealed that activation of ZAR1 forms a wheel-like pentamer, which has a funnel-shaped structure required for immune responsiveness and the CC domain of ZAR1 protein is directly necessary for oligomerization of ZAR1 and shaping a funnel-shaped structure [86]. In other reports, the TIR domain could cleave the metabolic cofactor nicotinamide adenine dinucleotide (NAD ${ }^{+}$) in response to pathogens for turning on downstream signaling [87,88].

\subsection{Ligand Recognition, Signaling, and Regulation}

Ligand recognition by intracellular immune receptors usually induces gene-for-gene resistance (also called effector-triggered immunity or ETI). ETI is typically associated with induced programmed cell death-based defense mechanism called hypersensitive reaction (HR) at locally infected spots [2]. For the resistance response to occur, ligand recognition by the receptor is only the initial step; there are complex downstream signaling steps to regulate immune response.

As a first layer for recognition of effectors or Avr factors secreted by pathogens, some intracellular immune receptors detect their ligands by direct interaction, which turns on defense signaling cascades [85]. For example, tomato I-2, which was introgressed from Solanum pimpinellifolium, recognizes Avr2 (also called Secreted in xylem 3, Six3) [89]. Structural-functional analyses of the Avr2 protein reveals that its recognition by the I-2 receptor is not based on surveillance of Avr2 activity in the plant cell, but direct interaction between Avr2 and I-2 [90]. Consistent with these findings, I-2 resistance-breaking Avr2 ${ }^{\mathrm{V} 41 \mathrm{M}}$, Avr2 ${ }^{\mathrm{R} 45 \mathrm{H}}$, and Avr2 ${ }^{\mathrm{R} 46 \mathrm{P}}$ variants, which have mutations on their surface-presented loop, showed normal virulence without recognition by the I-2 receptor $[90,91]$. This result demonstrated the evolutionary trajectories of the Avr2 effector to avoid I-2 receptor recognition.

There is unique example of direct recognition by intracellular immune receptor, which binds to a conserved PAMP-like region in its target effector. Tomato intracellular receptor Sw-5b recognizes a conserved peptide region $\mathrm{NSm}^{21}$ in the viral movement protein NSm from American-type tospoviruses [92]. The NB-ARC-LRR domain of Sw-5b could bind to $\mathrm{NSm}^{21}$ peptide directly, which weakens the interaction between NB-ARC and LRR domains thereby activating the downstream immune response [92]. In recent reports, Solanaceae domain of Sw-5b receptor binds to $\mathrm{NSm}^{21}$ and this interaction potentiates recognition of $\mathrm{NSm}^{21}$ by NB-ARC-LRR region, indicating Sw-5b receptor adopts a two-step recognition mechanism to improve viral effector perception [93].

On the other hand, other intracellular immune receptors indirectly detect their cognate effectors by sensing changes in the status of host proteins targeted by the Avr factors. For example, tobacco immune receptor $\mathrm{N}$ could recognize the p50 (50 kDa Helicase of tobacco mosaic virus) by interacting with NRIP1 (N receptor interacting protein 1). The NRIP1-p50 pre-complex allows subsequent interaction between the $\mathrm{N}$ receptor and NRIP1-p50 pre-complex for turning on downstream signaling for immunity [94]. 
Direct or indirect interactions between ligand and receptor induce recognition-mediated changes. These changes include: (1) Intramolecular interactions among domains in receptor, (2) intermolecular interactions among receptor and its interacting proteins, and (3) recruiting or losing nucleotide derivatives to turn on downstream signaling.

Intramolecular interaction is critical for the function of intracellular immune receptors, as demonstrated in Rx1. Potato immune receptor $\mathrm{Rx} 1$ confers high resistance to most Potato Virus $X$ strains and this resistance is initiated by recognition of the viral coat protein (CP) [95-97]. Like other receptors, intramolecular cooperation between domains of Rx1 is essential in sensing CP. Mechanistically, recognition of CP disrupts the interaction between its LRR and CC-NB-ARC domains. Recognition-mediated conformational changes and the nucleotide binding state of the protein determines immune activation [98].

Induced intermolecular interactions are also key during invasion pattern recognition and subsequent immune activation. Tomato Pto, which is the first isolated $\mathrm{R}$ gene and encodes a Serine/Threonine kinase, is involved in the direct recognition of two independent effectors AvrPto and AvrPtoB from Pseudomonas syringae, together with the tomato Prf NLR gene [99-102]. Although Pto kinase activity is not essential to bind to their ligand, it is necessary to activate the effector-receptor complex [103-105]. In detail, Prf protein could be oligomerized, which induces proximity of two Pto kinase molecules and when effector proteins bind to complexed Pto, this recognition induces trans-phosphorylation on Pto and activates downstream defense signaling $[101,106,107]$.

Because the function of immune receptors is directly linked to programmed cell death, it is crucial to maintain NLR proteins folded correctly for keeping their recognition-competent status. As interacting proteins of intracellular immune receptor, HSP90 chaperones and SGT1 (suppressor of the G2 allele of skp1) and RAR1 (required for Mla12 resistance) co-chaperones are involved in NLR-mediated signaling (for extensive review, see Shirasu [108], Kadota et al. [109], and Kadota and Shirasu, [110]).

There are several examples showing functions of HSP90 chaperone and its co-chaperone SGT1 and RAR1 in intracellular immune receptor-mediated resistance in Solanaceous plants. The Bs2 resistance gene was isolated from pepper plants resistant to strains of Xanthomonas campestris pv. vesicatoria expressing the effector protein AvrBs2 [111]. Through genetic and molecular biology approaches, the co-chaperone SGT1 was isolated as an interactor of the Bs2 protein in Nicotiana benthamiana and necessary for Bs2-AvrBs2-mediated resistance response [112]. In addition, CaSGT1 was identified as a host interactor of AvrBsT, a X. campestris pv vesicatoria type III effector protein. In pepper (Capsicum annuum), CaSGT1 is involved in AvrBsT-triggered hypersensitive reaction [113]. Interestingly, CaSGT1 could bind to CaPIK1, which was also previously reported to be involved in ETI by AvrBsT; CaPIK1-mediated phosphorylation was necessary to promote this response [113].

Recently, UBR7, which is a HECT-type E3 Ubiquitin ligase that recognizes the N-degron in mammals, wasfound to bind to the $\mathrm{N}$ immune receptor by proximity labeling [114]. Interestingly, UBR7 induces degradation of the $\mathrm{N}$ receptor during normal conditions [114]. When Tobacco mosaic virus (TMV) infects plant cells, p50 inhibits UBR7-mediated degradation of the $\mathrm{N}$ receptor by disrupting the interaction between UBR7 and the $\mathrm{N}$ receptor [114]. This stabilizes the $\mathrm{N}$ receptor only when TMV infection occurs [114].

Although NLR receptors are involved in recognition of their ligands as sensors, some NLRs function as helper receptors. For example, tobacco NRC2 (NLR required for cell death 2) and NRC3 are required for the function of the Prf receptor and NRC4 is required for the function of several NLR receptors including Rpi-blb2, Mi-1.2, and R1 [115]. In addition, NRG1 in Nicotiana benthamiana are also necessary for Roq1 (Recognition of XopQ 1) and RPP1-(Recognition of Peronospora parasitica 1) mediated resistance [116].

For proper activation of the immune response, subcellular partitioning of intracellular immune receptors is crucial. Through genetic and molecular approaches for dissecting downstream signaling, several plant proteins interacting with Rx1 have been identified. Among them, RanGTPase Activating 
Protein (RanGAP2), which is involved in nucleocytoplasmic shuttling, was reported to bind Rx1 receptor directly by affinity purification $[117,118]$. Indeed, RanGAP2 was necessary for Rx1-mediated HR and the RanGAP2-Rx1 interaction retained the Rx1 receptor in the cytoplasm [118,119]. Because hyper-accumulation of nuclear-localized $\mathrm{Rx} 1$ receptor by tagging its nuclear localization signal blocks HR and potato virus $\mathrm{x}(\mathrm{PVX})$ resistance, this demonstrates that a balanced nucleocytoplasmic partitioning of $R x$ is necessary for proper regulation of defense signaling $[119,120]$.

As mentioned above, tobacco immune receptor $\mathrm{N}$ could recognize the p50-NRIP1 pre-complex. In the absence of infection, NRIP1 protein usually localizes to the chloroplast [94]. After infection, however, the NRIP1 protein could sense and bind to p50; this interaction retains the p50-NRIP1 pre-complex in the cytoplasm, allowing subsequent recognition by $\mathrm{N}$ receptor in the cytoplasm [94].

Remarkably, pathogen effector proteins can affect recognition between another effector and its cognate receptor by regulating cell-to-cell movement of the effector. Six 5 (Secreted in xylem 5), which is an effector secreted by Fusarium oxysporum, is reported to be involved in I-2-mediated resistance [121]. Mechanistically, Six 5 localizes and interacts with Avr2 at the plasmodesmata and this interaction allows cell-to-cell movement of Avr2, which potentiates virulence in susceptible plants, but induces I-2-mediated resistance in I-2-containing plants [121].

Ultimately, re-organization of gene expression is achieved by recognition of the ligand through receptor-interacting transcription factors. Downstream of the N immune receptor complex, the SPL6 (SQUAMOSA PROMOTER BINDING PROTEIN (SBP)-domain transcription factor) associates with the $\mathrm{N}$ immune complex to induce the $\mathrm{N}$-mediated immune response [122]. Recently, the NbGlk1 (Golden2-like transcription factor) was also reported as another interacting protein of the $\mathrm{Rx} 1$ receptor [123]. Rx1 could regulate the binding affinity of NbGlk1 to its target DNA sequence, showing a direct mechanistic insight into how NLR activation coordinates immune signaling [123].

Table 2. Known intracellular immune receptors proteins in plant species of the Solanaceae family.

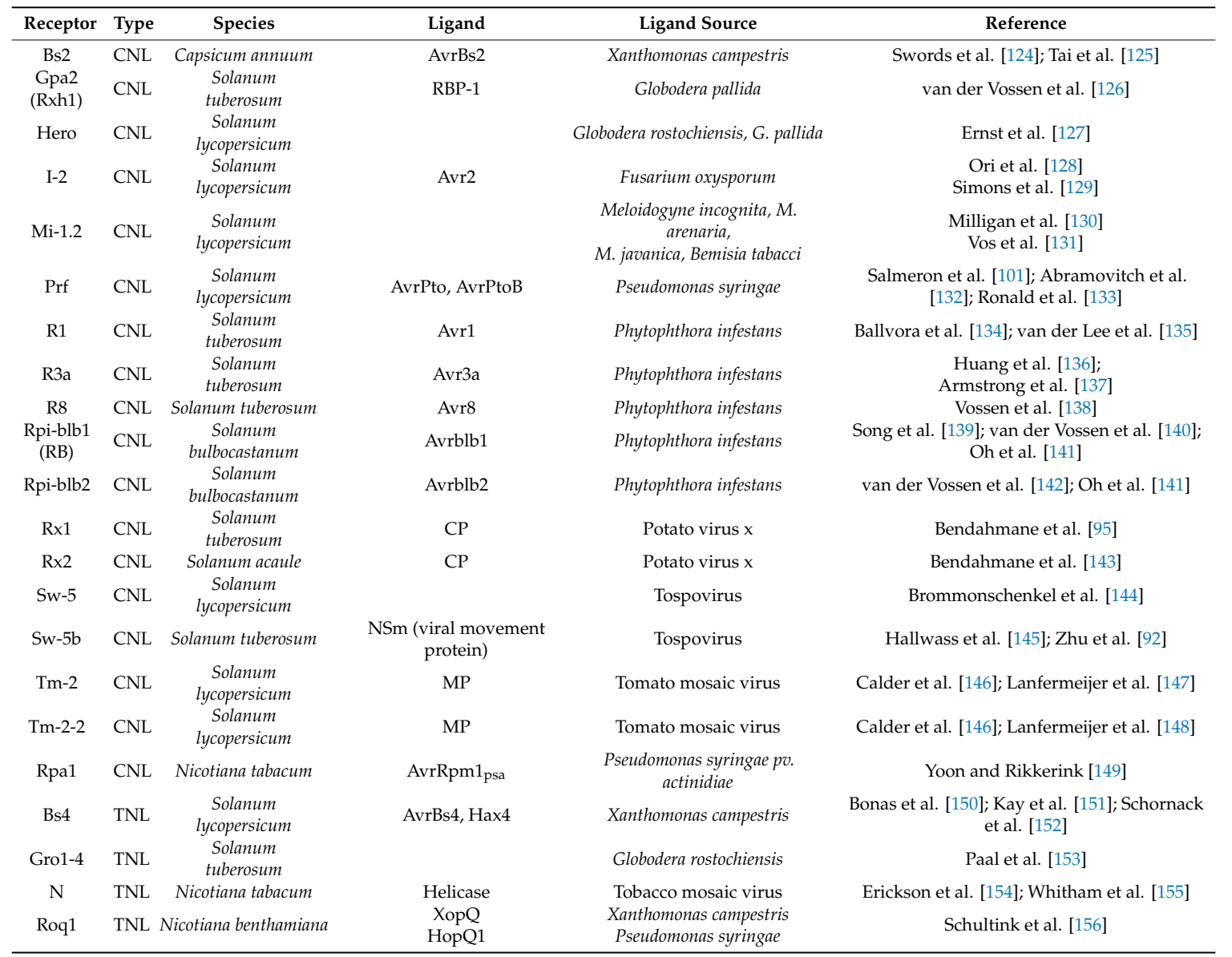




\section{Immune Receptor Crosstalk}

The distinction between cell surface receptor-mediated PTI and intracellular receptor-mediated ETI has not always been clear cut [157] based on overlapping transcriptome responses [158,159], proteome and phosphoproteome responses [160]. What seemingly sets ETI and PTI is the timing and duration of the immune response. Nonetheless, some exceptions to the supposedly distinct upstream elicitors and downstream defense responses have led to new models of the plant immune system (Figure 1) [161,162].

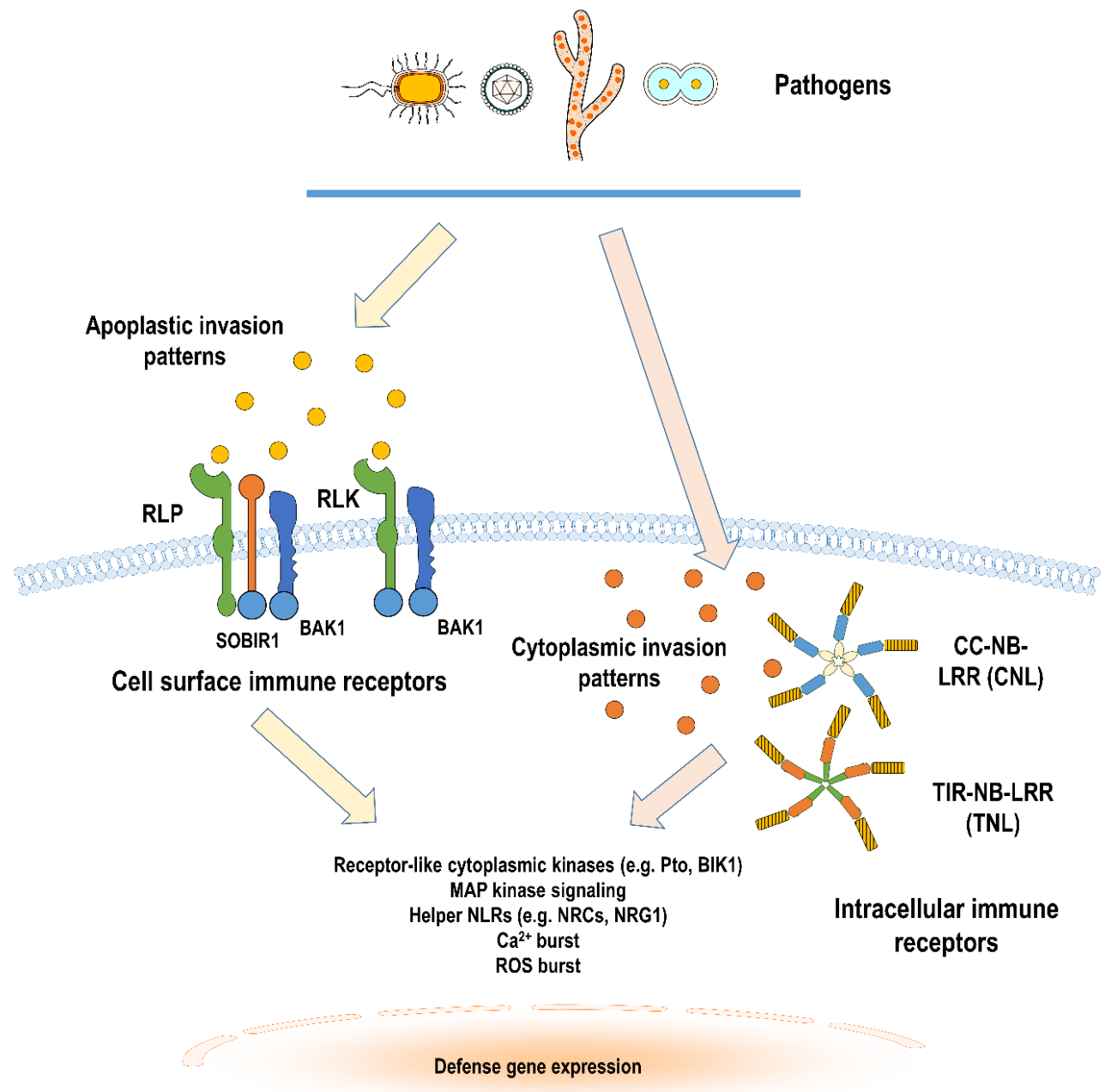

Figure 1. Model of cell surface and intracellular immune receptor-mediated defense signaling in Solanaceous plants. Invasion by pathogens are monitored by plant immune receptors located in the cell surface and cytoplasm. Apoplastic invasion patterns, such as conserved structural epitopes, are recognized by cell surface immune receptors-RLKs (receptor-like kinases), RLPs (receptor-like protein) and their co-receptors. Cytoplasmic invasion patterns such as virulence-promoting effectors are also monitored by NB-LRR (nucleotide-binding-leucine-rich repeat) receptors or NLRs, which could either have coiled coil (CC) or Toll/interleukin-1 receptor (TIR) domains in their N-terminal regions. Downstream of both these types of immune receptors, there are diverse molecular and cellular changes involved in turning on defense signaling. These signaling changes include interaction with various families of receptor kinases localized in the cytoplasm (like Pto and BIK1), phosphorylation cascades of MAP kinases, activation of convergent helper NLR proteins, and production of secondary messengers (like $\mathrm{Ca}^{2+}$ ) or reactive oxygen species (ROS). These ultimately lead to the differential regulation of various transcription factors to carefully tune gene expression according to the appropriate plant host defense output. (Generated in part using Motifolio Scientific Illustration Toolkits). 
Recently, the tomato NLR SINRC4a has been found to directly interact with the cell surface RLP EIX2 and RLK FLS2, providing a direct mechanistic link between the two types of immune receptors [163]. The RLK SERK1 associated with the NLR Mi-1.2 in vivo [164]. NLRs, like tomato NRC1 and tobacco NRC2 and NRC3, have also been shown to be required for immunity directed by the RLP Cf4 $[165,166]$. This is consistent with studies in Arabidopsis showing direct interaction between NLRs and the PRR FLS2 [167]. Therefore, it comes as no surprise that these two immune receptor types could be directly targeted and suppressed by a common pathogen effector, as shown in potato plants [168].

The transcription factor CAMTA (calmodulin binding transcription activator) has been identified as a convergent master transcription factor by negatively regulating both PTI- and ETI-associated genes in Arabidopsis [169]. Similarly, the tomato CAMTA homologs are involved in negatively regulating resistance to both biotrophic and nectrophic pathogens [170] but it remains to be seen if it directly regulates receptor-mediated immunity genes in tomato plants.

\section{Conclusions and Future Perspectives}

Excellent and ongoing advances in the study of the plant immune system have increased our understanding of the various immune receptors located at the cell surface and intracellularly. Several studies have provided tremendous insights on the diversity of dangers signal or patterns from the invading pathogen (or from the damaged host itself) recognized by these immune receptors. Although cell surface receptor-triggered and intracellular receptor-triggered immunity have typically been classified as PTI and ETI, respectively, it has been increasingly clear from several studies that these separate distinctions are blurred [157]. One of the most compelling models of the plant innate immune system is describing it as a delicate surveillance system of cell surface and intracellular sensor proteins that detect general invasion or danger signals, whether derived from the attacking pathogens or the damaged hosts $[18,161,162]$.

Inter-species transfer of immune receptor genes for heterologous expression have proven valuable to breeding plant resistance. Arabidopsis RLPs and RLKs, for example, have been transgenically effective in various solanaceous plants $[19,171-176]$. On the other hand, solanaceous immune receptors have been introduced to other species to enhance resistance. This was demonstrated by introducing tobacco FLS2 to Hamlin sweet orange and Carrizo citrange against Xanthomonas citri [177]. Tomato $\mathrm{Ve} 1$ and Ve2 also conferred resistance to V. alboatrum in potato independently [82]. Finally, chimeric receptor hybrids incorporating different domains from different plant clades have also shown novel possibility in producing more resistant plants [178-180].

Nonetheless, further research is still required in studying immunity of solanaceous plants, especially since this family represents several agriculturally important crop species and biologically important model species. There remain important knowledge gaps that need to be addressed in the near future. How are RLP/RLK and NLR genes regulated transcriptionally and post-transcriptionally at the mechanistic level, and how do these regulatory processes relate to the well-characterized signal transduction cascade following immune elicitation? How is proper immune homeostasis maintained in the cell through dephosphorylation events, repressor function and autophagy? How are cell surface and intracellular immune receptor proteins trafficked within the cell and what are the crucial molecular components? How similar or different are the downstream mechanisms in plants compared to metazoans? How is the cytoskeleton involved in these defense processes? How does the overlap of downstream molecular components of immune receptors contribute to the growth-defense balance in plants?

Comprehensive time-scale transcriptomic analyses together with higher-level proteomic, phosphoproteomic and translatomic approaches would allow elucidation of the RLP/RLK and NLR signaling mechanisms at the global level and provide clues on the regulatory hubs that integrate these two tiers of defense responses [160,181-183]. The use of mass spectrometry-based interactomic screens targeting various immune receptor protein of interest (under both mock and elicited conditions) 
could provide clues on downstream interacting proteins (both activator and repressor). Furthermore, newly discovered players in plant immunity are related to diverse processes like autophagy, vesicular trafficking and cytoskeleton [184-186]. Characterization of homologous solanaceous plant genes through CRISPR/Cas9 genome editing would expand our knowledge of genes that perturbs host resistance responses [187]. Downstream detailed phenotyping of these genome-edited plants in terms of biomass, photosynthetic rates and respiratory efficiency would allow us insights into the host's growth-defense balance.

Other interesting biological questions extend the dimension beyond binary host-pathogen interaction. How do various environmental factors affect immune receptor-mediated defense outputs and signaling events? How does the plant-microbiome crosstalk synergistically or antagonistically interact with immune receptor function and signaling? How can we harness natural variation in the plant immune system for breeding crop resistance?

It would be great to mechanistically investigate various environmental regimes and their impact on plant immune responses, with particular attention paid to specific molecular outputs related to surface and/or intracellular receptor signaling. For example, infection with the tomato leaf curl virus modulates molecular chaperones crucial for the heat tolerance response [188]. Further deciphering the mechanistic link of changing environmental factors to immune receptor signaling would prove important in identifying other vulnerable signaling regulators. Apart from looking at abiotic environmental parameters, examining the biotic contributions of the microbiome could inform future management and mitigation strategies. This would include assessing microbiota assembly in isogenic lines that differ in their resistance or testing differing synthetic communities $[189,190]$.

Finally, exploring beyond model solanaceous plants would open larger sources of continuously evolving immune receptor proteins. It has been shown that diverse tomato accessions were able to mount differential immune responses that relied on pattern-triggered immunity based on reporter genes as defense outputs. However, the receptors and molecular mechanisms still need to be identified and elucidated [191]. Together, these questions make the study of plant immunology quite exciting and rewarding in Solanaceae and beyond.

Author Contributions: Conceptualization, J.H.K. and C.D.M.C.; comprehensive survey and formal analyses of the literature, J.H.K. and C.D.M.C.; writing-original draft preparation, J.H.K. and C.D.M.C.; writing-review and editing, J.H.K. and C.D.M.C.; funding acquisition, C.D.M.C. All authors have read and agreed to the published version of the manuscript.

Funding: This work was supported by the Korea Research Fellowship (KRF) National Research Foundation (NRF-2018R1A6A3A03010644) to J.H.K. and a Wilfrid Laurier University institutional start-up fund to C.D.M.C.

Acknowledgments: The authors would like to thank Sheng Yang He (Michigan State University) for meaningful discussions regarding the preparation of this manuscript. We apologize to colleagues whose work we could not cite due to space limitations.

Conflicts of Interest: The authors declare no conflict of interest. The funders had no role in the design of the study; in the collection, analyses, or interpretation of data; in the writing of the manuscript, or in the decision to publish the results.

\section{References}

1. Strange, R.N.; Scott, P.R. Plant disease: A threat to global food security. Annu. Rev. Phytopathol. 2005, 43, 83-116. [CrossRef] [PubMed]

2. Bent, A.F.; Mackey, D. Elicitors, effectors, and R genes: The new paradigm and a lifetime supply of questions. Annu. Rev. Phytopathol. 2007, 45, 399-436. [CrossRef] [PubMed]

3. Boller, T.; Felix, G. A renaissance of elicitors: Perception of microbe-associated molecular patterns and danger signals by pattern-recognition receptors. Annu. Rev. Plant Biol. 2009, 60, 379-406. [CrossRef] [PubMed]

4. Velásquez, A.C.; Castroverde, C.D.M.; He, S.Y. Plant-pathogen warfare under changing climate conditions. Curr. Biol. 2018, 28, R619-R634. [CrossRef] [PubMed]

5. Albert, I.; Hua, C.; Nurnberger, T.; Pruitt, R.; Zhang, L. Surface sensor systems in plant immunity. Plant Physiol. 2019, in press. [CrossRef] 
6. Hind, S.R.; Strickler, S.R.; Boyle, P.C.; Dunham, D.M.; Bao, Z.; O’Doherty, I.M.; Baccile, J.A.; Hoki, J.S.; Viox, E.G.; Clarke, C.R.; et al. Tomato receptor FLAGELLIN-SENSING 3 binds flgII-28 and activates the plant immune system. Nat. Plants 2016, 2, 16128. [CrossRef]

7. Robatzek, S.; Bittel, P.; Chinchilla, D.; Köchner, P.; Felix, G.; Shiu, S.H.; Boller, T. Molecular identification and characterization of the tomato flagellin receptor LeFLS2, an orthologue of Arabidopsis FLS2 exhibiting characteristically different perception specificities. Plant Mol. Biol. 2007, 64, 539-547. [CrossRef]

8. Wang, L.; Einig, E.; Almeida-Trapp, M.; Albert, M.; Fliegmann, J.; Mithöfer, A.; Kalbacher, H.; Felix, G. The systemin receptor SYR1 enhances resistance of tomato against herbivorous insects. Nat. Plants 2018, 4, 152-156. [CrossRef]

9. Liao, D.; Sun, X.; Wang, N.; Song, F.; Liang, Y. Tomato LysM receptor-like kinase SILYK12 is involved in arbuscular mycorrhizal symbiosis. Front. Plant Sci. 2018, 9, 1004. [CrossRef]

10. Sanabria, N.M.; van Heerden, H.; Dubery, I.A. Molecular characterisation and regulation of a Nicotiana tabacum S-domain receptor-like kinase gene induced during an early rapid response to lipopolysaccharides. Gene 2012, 501, 39-48. [CrossRef]

11. Chen, D.; Cao, Y.; Li, H.; Kim, D.; Ahsan, N.; Thelen, J.; Stacey, G. Extracellular ATP elicits DORN1-mediated RBOHD phosphorylation to regulate stomatal aperture. Nat. Commun. 2017, 8, 2265. [CrossRef] [PubMed]

12. Lee, B.; Park, Y.S.; Lee, S.; Song, G.C.; Ryu, C.M. Bacterial RNAs activate innate immunity in Arabidopsis. New Phytol. 2016, 209, 785-797. [CrossRef] [PubMed]

13. Miya, A.; Albert, P.; Shinya, T.; Desaki, Y.; Ichimura, K.; Shirasu, K.; Narusaka, Y.; Kawakami, N.; Kaku, H.; Shibuya, N. CERK1, a LysM receptor kinase, is essential for chitin elicitor signaling in Arabidopsis. Proc. Natl. Acad. Sci. USA 2007, 104, 19613-19618. [CrossRef]

14. Zeng, L.; Velásquez, A.C.; Munkvold, K.R.; Zhang, J.; Martin, G.B. A tomato LysM receptor-like kinase promotes immunity and its kinase activity is inhibited by AvrPtoB. Plant J. 2012, 69, 92-103. [CrossRef] [PubMed]

15. Chinchilla, D.; Shan, L.; He, P.; de Vries, S.; Kemmerling, B. One for all: The receptor-associated kinase BAK1. Trends Plant Sci. 2009, 14, 535-541. [CrossRef] [PubMed]

16. Wang, L.; Albert, M.; Einig, E.; Fürst, U.; Krust, D.; Felix, G. The pattern-recognition receptor CORE of Solanaceae detects bacterial cold-shock protein. Nat. Plants 2016, 2, 16185. [CrossRef] [PubMed]

17. Liebrand, T.W.; van den Berg, G.C.; Zhang, Z.; Smit, P.; Cordewener, J.H.; America, A.H.; Sklenar, J.; Jones, A.M.; Tameling, W.I.; Robatzek, S.; et al. Receptor-Like kinase SOBIR1/EVR interacts with receptor-like proteins in plant immunity against fungal infection. Proc. Natl. Acad. Sci. USA 2013, 110, 10010-10015. [CrossRef]

18. Gust, A.A.; Felix, G. Receptor like proteins associate with SOBIR1-type of adaptors to form bimolecular receptor kinases. Curr. Opin. Plant Biol. 2014, 21, 104-111. [CrossRef]

19. Du, J.; Verzaux, E.; Chaparro-Garcia, A.; Bijsterbosch, G.; Keizer, L.C.; Zhou, J.; Liebrand, T.W.; Xie, C.; Govers, F.; Robatzek, S.; et al. Elicitin recognition confers enhanced resistance to Phytophthora infestans in potato. Nat. Plants 2015, 1, 15034. [CrossRef]

20. Liebrand, T.W.H.; van den Burg, H.A.; Joosten, M.H.A.J. Two for all: Receptor-Associated kinases SOBIR1 and BAK1. Trends Plant Sci. 2014, 19, 123-132. [CrossRef]

21. Hegenauer, V.; Fürst, U.; Kaiser, B.; Smoker, M.; Zipfel, C.; Felix, G.; Stahl, M.; Albert, M. Detection of the plant parasite Cuscuta reflexa by a tomato cell surface receptor. Science 2016, 353, 478-481. [CrossRef] [PubMed]

22. Sun, Y.; Li, L.; Macho, A.P.; Han, Z.; Hu, Z.; Zipfel, C.; Zhou, J.-M.; Chai, J. Structural basis for flg22-induced activation of the Arabidopsis FLS2-BAK1 immune complex. Science 2013, 342, 624-628. [CrossRef] [PubMed]

23. Peng, H.-C.; Kaloshian, I. The tomato leucine-rich repeat receptor-like kinases SISERK3A and SISERK3B have overlapping functions in bacterial and nematode innate immunity. PLoS ONE 2014, 9, e93302. [CrossRef] [PubMed]

24. Nietzschmann, L.; Gorzolka, K.; Smolka, U.; Matern, A.; Eschen-Lippold, L.; Scheel, D.; Rosahl, S. Early Pep-13-induced immune responses are SERK3A/B-dependent in potato. Sci. Rep. 2019, 9, 18380. [CrossRef]

25. Lu, D.; Wu, S.; Gao, X.; Zhang, Y.; Shan, L.; He, P. A receptor-like cytoplasmic kinase, BIK1, associates with a flagellin receptor complex to initiate plant innate immunity. Proc. Natl. Acad. Sci. USA 2010, 107, 496-501. [CrossRef] 
26. Abuqamar, S.; Chai, M.F.; Luo, H.; Song, F.; Mengiste, T. Tomato protein kinase $1 \mathrm{~b}$ mediates signaling of plant responses to necrotrophic fungi and insect herbivory. Plant Cell 2008, 20, 1964-1983. [CrossRef]

27. Schwizer, S.; Kraus, C.M.; Dunham, D.M.; Zheng, Y.; Fernandez-Pozo, N.; Pombo, M.A.; Fei, Z.; Chakravarthy, S.; Martin, G.B. The tomato kinase Pti1 contributes to production of reactive oxygen species in response to two flagellin-derived peptides and promotes resistance to Pseudomonas syringae infection. Mol. Plant Microbe Interact. 2017, 30, 725-738. [CrossRef]

28. Kim, D.S.; Hwang, B.K. The pepper receptor-like cytoplasmic protein kinase CaPIK1 is involved in plant signaling of defense and cell-death responses. Plant J. 2011, 66, 642-655. [CrossRef]

29. Kong, F.; Wang, J.; Cheng, L.; Liu, S.; Wu, J.; Peng, Z.; Lu, G. Genome-Wide analysis of the mitogen-activated protein kinase gene family in Solanum lycopersicum. Gene 2012, 499, 108-120. [CrossRef]

30. Wu, J.; Wang, J.; Pan, C.; Guan, X.; Wang, Y.; Liu, S.; He, Y.; Chen, J.; Chen, L.; Lu, G. Genome-Wide identification of MAPKK and MAPKKK gene families in tomato and transcriptional profiling analysis during development and stress response. PLoS ONE 2014, 9, e103032. [CrossRef]

31. Hu, Z.; Lv, X.; Xia, X.; Zhou, J.; Shi, K.; Yu, J.; Zhou, Y. Genome-Wide identification and expression analysis of calcium-dependent protein kinase in tomato. Front. Plant Sci. 2016, 7, 469. [CrossRef] [PubMed]

32. Asai, T.; Tena, G.; Plotnikova, J.; Willmann, M.R.; Chiu, W.L.; Gomez-Gomez, L.; Boller, T.; Ausubel, F.M.; Sheen, J. MAP kinase signalling cascade in Arabidopsis innate immunity. Nature 2002, 415, 977-983. [CrossRef] [PubMed]

33. Boudsocq, M.; Sheen, J. CDPKs in immune and stress signaling. Trends Plant Sci. 2013, 18, 30-40. [CrossRef] [PubMed]

34. Lindo, L.; Cardoza, R.E.; Lorenzana, A.; Casquero, P.A.; Gutiérrez, S. Identification of plant genes putatively involved in the perception of fungal ergosterol-squalene. J. Integr. Plant Biol. 2019. [CrossRef]

35. Katou, S.; Asakura, N.; Kojima, T.; Mitsuhara, I.; Seo, S. Transcriptome analysis of WIPK/SIPK-suppressed plants reveals induction by wounding of disease resistance-related genes prior to the accumulation of salicylic acid. Plant Cell Physiol. 2013, 54, 1005-1015. [CrossRef]

36. Nazar, R.N.; Castroverde, C.D.M.; Xu, X.; Kurosky, A.; Robb, J. Wounding induces tomato Ve1 R-gene expression. Planta 2019, 249, 1779-1797. [CrossRef]

37. Castroverde, C.D.; Xu, X.; Nazar, R.N.; Robb, J. Biotic factors that induce the tomato Ve1 R-gene. Plant Sci. 2017, 265, 61-69. [CrossRef]

38. Andolfo, G.; Ferriello, F.; Tardella, L.; Ferrarini, A.; Sigillo, L.; Frusciante, L.; Ercolano, M.R. Tomato genome-wide transcriptional responses to Fusarium wilt and tomato mosaic virus. PLoS ONE 2014, 9, e94963. [CrossRef]

39. Li, K.; Wu, G.; Li, M.; Ma, M.; Du, J.; Sun, M.; Sun, X.; Qing, L. Transcriptome analysis of Nicotiana benthamiana infected by Tobacco curly shoot virus. Virol. J. 2018, 15, 138. [CrossRef]

40. Zuluaga, A.P.; Vega-Arreguín, J.C.; Fei, Z.; Matas, A.J.; Patev, S.; Fry, W.E.; Rose, J.K. Analysis of the tomato leaf transcriptome during successive hemibiotrophic stages of a compatible interaction with the oomycete pathogen Phytophthora infestans. Mol. Plant Pathol. 2016, 17, 42-54. [CrossRef]

41. Thara, V.K.; Seilaniantz, A.R.; Deng, Y.; Dong, Y.; Yang, Y.; Tang, X.; Zhou, J.M. Tobacco genes induced by the bacterial effector protein AvrPto. Mol. Plant Microbe Interact. 2004, 17, 1139-1145. [CrossRef] [PubMed]

42. MacQueen, A.; Bergelson, J. Modulation of R-gene expression across environments. J. Exp. Bot. 2016, 67, 2093-2105. [CrossRef] [PubMed]

43. Wu, J.; Liu, Z.; Zhang, Z.; Lv, Y.; Yang, N.; Zhang, G.; Wu, M.; Lv, S.; Pan, L.; Joosten, M.H.; et al. Transcriptional regulation of receptor-like protein genes by environmental stresses and hormones and their overexpression activities in Arabidopsis thaliana. J. Exp. Bot. 2016, 67, 3339-3351. [CrossRef] [PubMed]

44. Cambiagno, D.A.; Nota, F.; Zavallo, D.; Rius, S.; Casati, P.; Asurmendi, S.; Alvarez, M.E. Immune receptor genes and pericentromeric transposons as targets of common epigenetic regulatory elements. Plant J. 2018, 96, 1178-1190. [CrossRef] [PubMed]

45. Sanabria, N.M.; Dubery, I.A. Alternative splicing of the receptor-like kinase Nt-Sd-RLK in tobacco cells responding to lipopolysaccharides: Suggestive of a role in pathogen surveillance and perception? FEBS Lett. 2016, 590, 3628-3638. [CrossRef]

46. Giska, F.; Martin, G.B. PP2C phosphatase Pic1 negatively regulates the phosphorylation status of Pti1b kinase, a regulator of flagellin-triggered immunity in tomato. Biochem. J. 2019, 476, 1621-1635. [CrossRef] 
47. Orosa, B.; Yates, G.; Verma, V.; Srivastava, A.K.; Srivastava, M.; Campanaro, A.; De Vega, D.; Fernandes, A.; Zhang, C.; Lee, J.; et al. SUMO conjugation to the pattern recognition receptor FLS2 triggers intracellular signalling in plant innate immunity. Nat. Commun. 2018, 9, 5185. [CrossRef]

48. Zhou, B.; Zeng, L. The tomato U-box type E3 ligase PUB13 acts with group III Ubiquitin E2 enzymes to modulate FLS2-mediated immune signaling. Front. Plant Sci. 2018, 9, 615. [CrossRef]

49. Taylor, K.W.; Kim, J.G.; Su, X.B.; Aakre, C.D.; Roden, J.A.; Adams, C.M.; Mudgett, M.B. Tomato TFT1 is required for PAMP-triggered immunity and mutations that prevent T3S effector XopN from binding to TFT1 attenuate Xanthomonas virulence. PLoS Pathog. 2012, 8, e1002768. [CrossRef]

50. Chen, L.; Hamada, S.; Fujiwara, M.; Zhu, T.; Thao, N.P.; Wong, H.L.; Krishna, P.; Ueda, T.; Kaku, H.; Shibuya, N.; et al. The Hop/Sti1-Hsp90 chaperone complex facilitates the maturation and transport of a PAMP receptor in rice innate immunity. Cell Host Microbe 2010, 7, 185-196. [CrossRef]

51. Huang, S.; Nie, S.; Wang, S.; Liu, J.; Zhang, Y.; Wang, X. SIBIR3 negatively regulates PAMP responses and cell death in tomato. Int. J. Mol. Sci. 2017, 18, 1966. [CrossRef] [PubMed]

52. Pizarro, L.; Leibman-Markus, M.; Schuster, S.; Bar, M.; Meltz, T.; Avni, A. Tomato prenylated RAB acceptor protein 1 modulates trafficking and degradation of the pattern recognition receptor LeEIX2, affecting the innate immune response. Front. Plant Sci. 2018, 9, 257. [CrossRef] [PubMed]

53. Bar, M.; Avni, A. EHD2 inhibits ligand-induced endocytosis and signaling of the leucine-rich repeat receptor-like protein LeEix2. Plant J. 2009, 59, 600-611. [CrossRef] [PubMed]

54. Korasick, D.A.; McMichael, C.; Walker, K.A.; Anderson, J.C.; Bednarek, S.Y.; Heese, A. Novel functions of Stomatal Cytokinesis-Defective 1 (SCD1) in innate immune responses against bacteria. J. Biol. Chem. 2010, 285, 23342-23350. [CrossRef] [PubMed]

55. Spallek, T.; Beck, M.; Ben Khaled, S.; Salomon, S.; Bourdais, G.; Schellmann, S.; Robatzek, S. ESCRT-I mediates FLS2 endosomal sorting and plant immunity. PLoS Genet. 2013, 9, e1004035. [CrossRef]

56. Saur, I.M.; Kadota, Y.; Sklenar, J.; Holton, N.J.; Smakowska, E.; Belkhadir, Y.; Zipfel, C.; Rathjen, J.P. NbCSPR underlies age-dependent immune responses to bacterial cold shock protein in Nicotiana benthamiana. Proc. Natl. Acad. Sci. USA 2016, 113, 3389-3394. [CrossRef]

57. Catanzariti, A.M.; Lim, G.T.; Jones, D.A. The tomato I-3 gene: A novel gene for resistance to Fusarium wilt disease. New Phytol. 2015, 207, 106-118. [CrossRef]

58. Wang, H.; Chen, Y.; Wu, X.; Long, Z.; Sun, C.; Wang, S.; Birch, P.R.J.; Tian, Z. A potato STRUBBELIG-RECEPTOR FAMILY member, StLRPK1, associates with StSERK3A/BAK1 and activates immunity. J. Exp. Bot. 2018, 69, 5573-5586. [CrossRef]

59. Lori, M.; van Verk, M.C.; Hander, T.; Schatowitz, H.; Klauser, D.; Flury, P.; Gehring, C.A.; Boller, T.; Bartels, S. Evolutionary divergence of the plant elicitor peptides (Peps) and their receptors: Interfamily incompatibility of perception but compatibility of downstream signalling. J. Exp. Bot. 2015, 66, 5315-5325. [CrossRef]

60. Zhang, H.; Hu, Z.; Lei, C.; Zheng, C.; Wang, J.; Shao, S.; Li, X.; Xia, X.; Cai, X.; Zhou, J.; et al. A plant phytosulfokine peptide initiates auxin-dependent immunity through cytosolic Ca. Plant Cell 2018, 30, 652-667. [CrossRef]

61. Sun, M.; Voorrips, R.E.; Steenhuis-Broers, G.; Van't Westende, W.; Vosman, B. Reduced phloem uptake of Myzus persicae on an aphid resistant pepper accession. BMC Plant Biol. 2018, 18, 138. [CrossRef] [PubMed]

62. Scheer, J.M.; Ryan, C.A. The systemin receptor SR160 from Lycopersicon peruvianum is a member of the LRR receptor kinase family. Proc. Natl. Acad. Sci. USA 2002, 99, 9585-9590. [CrossRef] [PubMed]

63. Dixon, M.S.; Jones, D.A.; Keddie, J.S.; Thomas, C.M.; Harrison, K.; Jones, J.D. The tomato Cf-2 disease resistance locus comprises two functional genes encoding leucine-rich repeat proteins. Cell 1996, 84, 451-459. [CrossRef]

64. Jones, D.A.; Brading, P.; Dixon, M.; Hammond-Kosack, K.; Harrison, K.; Hatzixanthis, K.; Parniske, M.; Piedras, P.; Torres, M.; Tang, S.; et al. Molecular, genetic and physiological analysis of Cladosporium resistance gene function in tomato. Symp. Soc. Exp. Biol. 1998, 51, 111-113. [PubMed]

65. Thomas, C.M.; Dixon, M.S.; Parniske, M.; Golstein, C.; Jones, J.D. Genetic and molecular analysis of tomato Cf genes for resistance to Cladosporium fulvum. Philos. Trans. R. Soc. Lond. B Biol. Sci. 1998, 353, 1413-1424. [CrossRef] [PubMed]

66. Thomas, C.M.; Jones, D.A.; Parniske, M.; Harrison, K.; Balint-Kurti, P.J.; Hatzixanthis, K.; Jones, J.D. Characterization of the tomato Cf-4 gene for resistance to Cladosporium fulvum identifies sequences that determine recognitional specificity in Cf-4 and Cf-9. Plant Cell 1997, 9, 2209-2224. [PubMed] 
67. Takken, F.L.; Thomas, C.M.; Joosten, M.H.; Golstein, C.; Westerink, N.; Hille, J.; Nijkamp, H.J.; De Wit, P.J.; Jones, J.D. A second gene at the tomato Cf-4 locus confers resistance to Cladosporium fulvum through recognition of a novel avirulence determinant. Plant J. 1999, 20, 279-288. [CrossRef]

68. Takken, F.L.; Schipper, D.; Nijkamp, H.J.; Hille, J. Identification and Ds-tagged isolation of a new gene at the Cf-4 locus of tomato involved in disease resistance to Cladosporium fulvum race 5. Plant J. 1998, 14, 401-411. [CrossRef]

69. Dixon, M.S.; Hatzixanthis, K.; Jones, D.A.; Harrison, K.; Jones, J.D. The tomato Cf-5 disease resistance gene and six homologs show pronounced allelic variation in leucine-rich repeat copy number. Plant Cell 1998, 10, 1915-1925. [CrossRef]

70. Grushtskaia, Z.E.; Lemesh, V.A.; Poliksenova, V.D.; Khotyleva, L.V. Cloning of the Cf-6 tomato leaf mould resistance locus using SSR markers. Genetika 2007, 43, 1511-1516.

71. Jones, D.A.; Thomas, C.M.; Hammond-Kosack, K.E.; Balint-Kurti, P.J.; Jones, J.D. Isolation of the tomato Cf-9 gene for resistance to Cladosporium fulvum by transposon tagging. Science 1994, 266, 789-793. [CrossRef] [PubMed]

72. Hammond-Kosack, K.E.; Harrison, K.; Jones, J.D. Developmentally regulated cell death on expression of the fungal avirulence gene Avr9 in tomato seedlings carrying the disease-resistance gene Cf-9. Proc. Natl. Acad. Sci. USA 1994, 91, 10445-10449. [CrossRef] [PubMed]

73. Hammond-Kosack, K.E.; Tang, S.; Harrison, K.; Jones, J.D. The tomato Cf-9 disease resistance gene functions in tobacco and potato to confer responsiveness to the fungal avirulence gene product avr 9. Plant Cell 1998, 10, 1251-1266. [CrossRef] [PubMed]

74. van der Hoorn, R.A.; Wulff, B.B.; Rivas, S.; Durrant, M.C.; van der Ploeg, A.; de Wit, P.J.; Jones, J.D. Structure-Function analysis of cf-9, a receptor-like protein with extracytoplasmic leucine-rich repeats. Plant Cell 2005, 17, 1000-1015. [CrossRef]

75. Parniske, M.; Wulff, B.B.; Bonnema, G.; Thomas, C.M.; Jones, D.A.; Jones, J.D. Homologues of the Cf-9 disease resistance gene (Hcr9s) are present at multiple loci on the short arm of tomato chromosome 1. Mol. Plant Microbe Interact. 1999, 12, 93-102. [CrossRef]

76. Laugé, R.; Joosten, M.H.; Haanstra, J.P.; Goodwin, P.H.; Lindhout, P.; De Wit, P.J. Successful search for a resistance gene in tomato targeted against a virulence factor of a fungal pathogen. Proc. Natl. Acad. Sci. USA 1998, 95, 9014-9018. [CrossRef]

77. Ron, M.; Avni, A. The receptor for the fungal elicitor ethylene-inducing xylanase is a member of a resistance-like gene family in tomato. Plant Cell 2004, 16, 1604-1615. [CrossRef]

78. Bar, M.; Sharfman, M.; Ron, M.; Avni, A. BAK1 is required for the attenuation of ethylene-inducing xylanase (Eix)-induced defense responses by the decoy receptor LeEix1. Plant J. 2010, 63, 791-800. [CrossRef]

79. Catanzariti, A.M.; Do, H.T.; Bru, P.; de Sain, M.; Thatcher, L.F.; Rep, M.; Jones, D.A. The tomato I gene for Fusarium wilt resistance encodes an atypical leucine-rich repeat receptor-like protein whose function is nevertheless dependent on SOBIR1 and SERK3/BAK1. Plant J. 2017, 89, 1195-1209. [CrossRef]

80. Gonzalez-Cendales, Y.; Catanzariti, A.M.; Baker, B.; Mcgrath, D.J.; Jones, D.A. Identification of I-7 expands the repertoire of genes for resistance to Fusarium wilt in tomato to three resistance gene classes. Mol. Plant Pathol. 2016, 17, 448-463. [CrossRef]

81. Wang, Y.; Xu, Y.; Sun, Y.; Wang, H.; Qi, J.; Wan, B.; Ye, W.; Lin, Y.; Shao, Y.; Dong, S.; et al. Leucine-Rich repeat receptor-like gene screen reveals that Nicotiana RXEG1 regulates glycoside hydrolase 12 MAMP detection. Nat. Commun. 2018, 9, 594. [CrossRef] [PubMed]

82. Kawchuk, L.M.; Hachey, J.; Lynch, D.R.; Kulcsar, F.; van Rooijen, G.; Waterer, D.R.; Robertson, A.; Kokko, E.; Byers, R.; Howard, R.J.; et al. Tomato Ve disease resistance genes encode cell surface-like receptors. Proc. Natl. Acad. Sci. USA 2001, 98, 6511-6515. [CrossRef] [PubMed]

83. Fradin, E.F.; Zhang, Z.; Juarez Ayala, J.C.; Castroverde, C.D.M.; Nazar, R.N.; Robb, J.; Liu, C.-M.; Thomma, B.P.H.J. Genetic dissection of Verticillium wilt resistance mediated by tomato Ve1. Plant Physiol. 2009, 150, 320-332. [CrossRef] [PubMed]

84. Nazar, R.N.; Xu, X.; Kurosky, A.; Robb, J. Antagonistic function of the Ve R-genes in tomato. Plant Mol. Biol. 2018, 98, 67-79. [CrossRef] [PubMed]

85. van Ooijen, G.; van den Burg, H.A.; Cornelissen, B.J.; Takken, F.L. Structure and function of resistance proteins in solanaceous plants. Annu. Rev. Phytopathol. 2007, 45, 43-72. [CrossRef] [PubMed] 
86. Wang, J.; Hu, M.; Qi, J.; Han, Z.; Wang, G.; Qi, Y.; Wang, H.W.; Zhou, J.M.; Chai, J. Reconstitution and structure of a plant NLR resistosome conferring immunity. Science 2019, 364. [CrossRef]

87. Horsefield, S.; Burdett, H.; Zhang, X.; Manik, M.K.; Shi, Y.; Chen, J.; Qi, T.; Gilley, J.; Lai, J.-S.; Rank, M.X.; et al. NAD ${ }^{+}$cleavage activity by animal and plant TIR domains in cell death pathways. Science 2019, 365, 793-799. [CrossRef]

88. Wan, L.; Essuman, K.; Anderson, R.G.; Sasaki, Y.; Monteiro, F.; Chung, E.H.; Osborne Nishimura, E.; DiAntonio, A.; Milbrandt, J.; Dangl, J.L.; et al. TIR domains of plant immune receptors are NAD. Science 2019, 365, 799-803. [CrossRef]

89. Houterman, P.M.; Ma, L.; van Ooijen, G.; de Vroomen, M.J.; Cornelissen, B.J.; Takken, F.L.; Rep, M. The effector protein Avr2 of the xylem-colonizing fungus Fusarium oxysporum activates the tomato resistance protein I-2 intracellularly. Plant J. 2009, 58, 970-978. [CrossRef]

90. Di, X.; Cao, L.; Hughes, R.K.; Tintor, N.; Banfield, M.J.; Takken, F.L.W. Structure-Function analysis of the Fusarium oxysporum Avr2 effector allows uncoupling of its immune-suppressing activity from recognition. New Phytol. 2017, 216, 897-914. [CrossRef]

91. Biju, V.C.; Fokkens, L.; Houterman, P.M.; Rep, M.; Cornelissen, B.J.C. Multiple evolutionary trajectories have led to the emergence of races in Fusarium oxysporum f. sp. lycopersici. Appl. Environ. Microbiol. 2017, 83. [CrossRef] [PubMed]

92. Zhu, M.; Jiang, L.; Bai, B.; Zhao, W.; Chen, X.; Li, J.; Liu, Y.; Chen, Z.; Wang, B.; Wang, C.; et al. The intracellular immune receptor $\mathrm{Sw}-5 \mathrm{~b}$ confers broad-spectrum resistance to tospoviruses through recognition of a conserved 21-amino acid viral effector epitope. Plant Cell 2017, 29, 2214-2232. [CrossRef] [PubMed]

93. Li, J.; Huang, H.; Zhu, M.; Huang, S.; Zhang, W.; Dinesh-Kumar, S.P.; Tao, X. A plant immune receptor adopts a two-step recognition mechanism to enhance viral effector perception. Mol. Plant 2019, 12, 248-262. [CrossRef] [PubMed]

94. Caplan, J.L.; Mamillapalli, P.; Burch-Smith, T.M.; Czymmek, K.; Dinesh-Kumar, S.P. Chloroplastic protein NRIP1 mediates innate immune receptor recognition of a viral effector. Cell 2008, 132, 449-462. [CrossRef] [PubMed]

95. Bendahmane, A.; Köhn, B.A.; Dedi, C.; Baulcombe, D.C. The coat protein of potato virus X is a strain-specific elicitor of Rx1-mediated virus resistance in potato. Plant J. 1995, 8, 933-941. [CrossRef] [PubMed]

96. Ritter, E.; Debener, T.; Barone, A.; Salamini, F.; Gebhardt, C. RFLP mapping on potato chromosomes of two genes controlling extreme resistance to potato virus X (PVX). Mol. Gen. Genet. 1991, 227, 81-85. [CrossRef]

97. Santa Cruz, S.; Baulcombe, D. Analysis of potato virus $X$ coat protein genes in relation to resistance conferred by the genes Nx, Nb and Rx1 of potato. J. Gen. Virol. 1995, 76 Pt 8, 2057-2061. [CrossRef]

98. Slootweg, E.J.; Spiridon, L.N.; Roosien, J.; Butterbach, P.; Pomp, R.; Westerhof, L.; Wilbers, R.; Bakker, E.; Bakker, J.; Petrescu, A.J.; et al. Structural determinants at the interface of the ARC2 and leucine-rich repeat domains control the activation of the plant immune receptors Rx1 and Gpa2. Plant Physiol. 2013, 162, 1510-1528. [CrossRef]

99. Kim, Y.J.; Lin, N.C.; Martin, G.B. Two distinct Pseudomonas effector proteins interact with the Pto kinase and activate plant immunity. Cell 2002, 109, 589-598. [CrossRef]

100. Martin, G.B.; Brommonschenkel, S.H.; Chunwongse, J.; Frary, A.; Ganal, M.W.; Spivey, R.; Wu, T.; Earle, E.D.; Tanksley, S.D. Map-Based cloning of a protein kinase gene conferring disease resistance in tomato. Science 1993, 262, 1432-1436. [CrossRef]

101. Salmeron, J.M.; Oldroyd, G.E.; Rommens, C.M.; Scofield, S.R.; Kim, H.S.; Lavelle, D.T.; Dahlbeck, D.; Staskawicz, B.J. Tomato Prf is a member of the leucine-rich repeat class of plant disease resistance genes and lies embedded within the Pto kinase gene cluster. Cell 1996, 86, 123-133. [CrossRef]

102. Tang, X.; Frederick, R.D.; Zhou, J.; Halterman, D.A.; Jia, Y.; Martin, G.B. Initiation of plant disease resistance by physical interaction of AvrPto and Pto kinase. Science 1996, 274, 2060-2063. [CrossRef] [PubMed]

103. Ntoukakis, V.; Balmuth, A.L.; Mucyn, T.S.; Gutierrez, J.R.; Jones, A.M.; Rathjen, J.P. The tomato Prf complex is a molecular trap for bacterial effectors based on Pto transphosphorylation. PLoS Pathog. 2013, 9, e1003123. [CrossRef] [PubMed]

104. Wu, A.J.; Andriotis, V.M.; Durrant, M.C.; Rathjen, J.P. A patch of surface-exposed residues mediates negative regulation of immune signaling by tomato Pto kinase. Plant Cell 2004, 16, 2809-2821. [CrossRef] 
105. Xing, W.; Zou, Y.; Liu, Q.; Liu, J.; Luo, X.; Huang, Q.; Chen, S.; Zhu, L.; Bi, R.; Hao, Q.; et al. The structural basis for activation of plant immunity by bacterial effector protein AvrPto. Nature 2007, 449, 243-247. [CrossRef]

106. Mucyn, T.S.; Clemente, A.; Andriotis, V.M.E.; Balmuth, A.L.; Oldroyd, G.E.D.; Staskawicz, B.J.; Rathjen, J.P. The tomato NBARC-LRR protein Prf interacts with Pto kinase In Vivo to regulate specific plant immunity. Plant Cell 2006, 18, 2792-2806. [CrossRef]

107. Ntoukakis, V.; Saur, I.M.; Conlan, B.; Rathjen, J.P. The changing of the guard: The Pto/Prf receptor complex of tomato and pathogen recognition. Curr. Opin. Plant Biol. 2014, 20, 69-74. [CrossRef]

108. Shirasu, K. The HSP90-SGT1 chaperone complex for NLR immune sensors. Annu. Rev. Plant Biol. 2009, 60, 139-164. [CrossRef] [PubMed]

109. Kadota, Y.; Shirasu, K.; Guerois, R. NLR sensors meet at the SGT1-HSP90 crossroad. Trends Biochem. Sci. 2010, 35, 199-207. [CrossRef] [PubMed]

110. Kadota, Y.; Shirasu, K. The HSP90 complex of plants. Biochim. Biophys. Acta 2012, 1823, 689-697. [CrossRef] [PubMed]

111. Kearney, B.; Staskawicz, B.J. Widespread distribution and fitness contribution of Xanthomonas campestris avirulence gene avrBs2. Nature 1990, 346, 385-386. [CrossRef]

112. Leister, R.T.; Dahlbeck, D.; Day, B.; Li, Y.; Chesnokova, O.; Staskawicz, B.J. Molecular genetic evidence for the role of SGT1 in the intramolecular complementation of Bs2 protein activity in Nicotiana benthamiana. Plant Cell 2005, 17, 1268-1278. [CrossRef] [PubMed]

113. Han, S.W.; Hwang, B.K. Molecular functions of Xanthomonas type III effector AvrBsT and its plant interactors in cell death and defense signaling. Planta 2017, 245, 237-253. [CrossRef]

114. Zhang, Y.; Song, G.; Lal, N.K.; Nagalakshmi, U.; Li, Y.; Zheng, W.; Huang, P.J.; Branon, T.C.; Ting, A.Y.; Walley, J.W.; et al. TurboID-Based proximity labeling reveals that UBR7 is a regulator of N NLR immune receptor-mediated immunity. Nat. Commun. 2019, 10, 3252. [CrossRef] [PubMed]

115. Wu, C.H.; Abd-El-Haliem, A.; Bozkurt, T.O.; Belhaj, K.; Terauchi, R.; Vossen, J.H.; Kamoun, S. NLR network mediates immunity to diverse plant pathogens. Proc. Natl. Acad. Sci. USA 2017, 114, 8113-8118. [CrossRef] [PubMed]

116. Qi, T.; Seong, K.; Thomazella, D.P.T.; Kim, J.R.; Pham, J.; Seo, E.; Cho, M.J.; Schultink, A.; Staskawicz, B.J. NRG1 functions downstream of EDS1 to regulate TIR-NLR-mediated plant immunity in. Proc. Natl. Acad. Sci. USA 2018, 115, E10979-E10987. [CrossRef]

117. Sacco, M.A.; Mansoor, S.; Moffett, P. A RanGAP protein physically interacts with the NB-LRR protein Rx, and is required for Rx-mediated viral resistance. Plant J. 2007, 52, 82-93. [CrossRef]

118. Tameling, W.I.; Baulcombe, D.C. Physical association of the NB-LRR resistance protein Rx with a Ran GTPase-activating protein is required for extreme resistance to Potato virus X. Plant Cell 2007, 19, 1682-1694. [CrossRef]

119. Tameling, W.I.; Nooijen, C.; Ludwig, N.; Boter, M.; Slootweg, E.; Goverse, A.; Shirasu, K.; Joosten, M.H. RanGAP2 mediates nucleocytoplasmic partitioning of the NB-LRR immune receptor Rx in the Solanaceae, thereby dictating Rx function. Plant Cell 2010, 22, 4176-4194. [CrossRef]

120. Slootweg, E.; Roosien, J.; Spiridon, L.N.; Petrescu, A.J.; Tameling, W.; Joosten, M.; Pomp, R.; van Schaik, C.; Dees, R.; Borst, J.W.; et al. Nucleocytoplasmic distribution is required for activation of resistance by the potato NB-LRR receptor Rx1 and is balanced by its functional domains. Plant Cell 2010, 22, 4195-4215. [CrossRef]

121. Cao, L.; Blekemolen, M.C.; Tintor, N.; Cornelissen, B.J.C.; Takken, F.L.W. The Fusarium oxysporum Avr2-Six5 effector pair alters plasmodesmatal exclusion selectivity to facilitate cell-to-cell movement of Avr2. Mol. Plant 2018, 11, 691-705. [CrossRef] [PubMed]

122. Padmanabhan, M.S.; Ma, S.; Burch-Smith, T.M.; Czymmek, K.; Huijser, P.; Dinesh-Kumar, S.P. Novel positive regulatory role for the SPL6 transcription factor in the N TIR-NB-LRR receptor-mediated plant innate immunity. PLoS Pathog. 2013, 9, e1003235. [CrossRef] [PubMed]

123. Townsend, P.D.; Dixon, C.H.; Slootweg, E.J.; Sukarta, O.C.A.; Yang, A.W.H.; Hughes, T.R.; Sharples, G.J.; Palsson, L.O.; Takken, F.L.W.; Goverse, A.; et al. The intracellular immune receptor Rx1 regulates the DNA-binding activity of a Golden2-like transcription factor. J. Biol. Chem. 2018, 293, 3218-3233. [CrossRef] [PubMed] 
124. Swords, K.M.; Dahlbeck, D.; Kearney, B.; Roy, M.; Staskawicz, B.J. Spontaneous and induced mutations in a single open reading frame alter both virulence and avirulence in Xanthomonas campestris pv. vesicatoria avrBs2. J. Bacteriol. 1996, 178, 4661-4669. [CrossRef]

125. Tai, T.H.; Dahlbeck, D.; Clark, E.T.; Gajiwala, P.; Pasion, R.; Whalen, M.C.; Stall, R.E.; Staskawicz, B.J. Expression of the Bs2 pepper gene confers resistance to bacterial spot disease in tomato. Proc. Natl. Acad. Sci. USA 1999, 96, 14153-14158. [CrossRef]

126. van der Vossen, E.A.; van der Voort, J.N.; Kanyuka, K.; Bendahmane, A.; Sandbrink, H.; Baulcombe, D.C.; Bakker, J.; Stiekema, W.J.; Klein-Lankhorst, R.M. Homologues of a single resistance-gene cluster in potato confer resistance to distinct pathogens: A virus and a nematode. Plant J. 2000, 23, 567-576. [CrossRef]

127. Ernst, K.; Kumar, A.; Kriseleit, D.; Kloos, D.U.; Phillips, M.S.; Ganal, M.W. The broad-spectrum potato cyst nematode resistance gene (Hero) from tomato is the only member of a large gene family of NBS-LRR genes with an unusual amino acid repeat in the LRR region. Plant J. 2002, 31, 127-136. [CrossRef]

128. Ori, N.; Eshed, Y.; Paran, I.; Presting, G.; Aviv, D.; Tanksley, S.; Zamir, D.; Fluhr, R. The I2C family from the wilt disease resistance locus $\mathrm{I} 2$ belongs to the nucleotide binding, leucine-rich repeat superfamily of plant resistance genes. Plant Cell 1997, 9, 521-532. [CrossRef]

129. Simons, G.; Groenendijk, J.; Wijbrandi, J.; Reijans, M.; Groenen, J.; Diergaarde, P.; Van der Lee, T.; Bleeker, M.; Onstenk, J.; de Both, M.; et al. Dissection of the Fusarium I2 gene cluster in tomato reveals six homologs and one active gene copy. Plant Cell 1998, 10, 1055-1068. [CrossRef]

130. Milligan, S.B.; Bodeau, J.; Yaghoobi, J.; Kaloshian, I.; Zabel, P.; Williamson, V.M. The root knot nematode resistance gene $\mathrm{Mi}$ from tomato is a member of the leucine zipper, nucleotide binding, leucine-rich repeat family of plant genes. Plant Cell 1998, 10, 1307-1319. [CrossRef]

131. Vos, P.; Simons, G.; Jesse, T.; Wijbrandi, J.; Heinen, L.; Hogers, R.; Frijters, A.; Groenendijk, J.; Diergaarde, P.; Reijans, M.; et al. The tomato Mi-1 gene confers resistance to both root-knot nematodes and potato aphids. Nat. Biotechnol. 1998, 16, 1365-1369. [CrossRef] [PubMed]

132. Abramovitch, R.B.; Kim, Y.J.; Chen, S.; Dickman, M.B.; Martin, G.B. Pseudomonas type III effector AvrPtoB induces plant disease susceptibility by inhibition of host programmed cell death. EMBO J. 2003, 22, 60-69. [CrossRef] [PubMed]

133. Ronald, P.C.; Salmeron, J.M.; Carland, F.M.; Staskawicz, B.J. The cloned avirulence gene avrPto induces disease resistance in tomato cultivars containing the Pto resistance gene. J. Bacteriol. 1992, 174, 1604-1611. [CrossRef] [PubMed]

134. Ballvora, A.; Ercolano, M.R.; Weiss, J.; Meksem, K.; Bormann, C.A.; Oberhagemann, P.; Salamini, F.; Gebhardt, C. The R1 gene for potato resistance to late blight (Phytophthora infestans) belongs to the leucine zipper/NBS/LRR class of plant resistance genes. Plant J. 2002, 30, 361-371. [CrossRef] [PubMed]

135. van der Lee, T.; Testa, A.; Robold, A.; van 't Klooster, J.; Govers, F. High-Density genetic linkage maps of Phytophthora infestans reveal trisomic progeny and chromosomal rearrangements. Genetics 2004, 167, 1643-1661. [CrossRef] [PubMed]

136. Huang, S.; van der Vossen, E.A.; Kuang, H.; Vleeshouwers, V.G.; Zhang, N.; Borm, T.J.; van Eck, H.J.; Baker, B.; Jacobsen, E.; Visser, R.G. Comparative genomics enabled the isolation of the R3a late blight resistance gene in potato. Plant J. 2005, 42, 251-261. [CrossRef]

137. Armstrong, M.R.; Whisson, S.C.; Pritchard, L.; Bos, J.I.; Venter, E.; Avrova, A.O.; Rehmany, A.P.; Böhme, U.; Brooks, K.; Cherevach, I.; et al. An ancestral oomycete locus contains late blight avirulence gene Avr3a, encoding a protein that is recognized in the host cytoplasm. Proc. Natl. Acad. Sci. USA 2005, 102, 7766-7771. [CrossRef]

138. Vossen, J.H.; van Arkel, G.; Bergervoet, M.; Jo, K.R.; Jacobsen, E.; Visser, R.G. The Solanum demissum R8 late blight resistance gene is an $\mathrm{Sw}-5$ homologue that has been deployed worldwide in late blight resistant varieties. Theor. Appl. Genet. 2016, 129, 1785-1796. [CrossRef]

139. Song, J.; Bradeen, J.M.; Naess, S.K.; Raasch, J.A.; Wielgus, S.M.; Haberlach, G.T.; Liu, J.; Kuang, H.; Austin-Phillips, S.; Buell, C.R.; et al. Gene RB cloned from Solanum bulbocastanum confers broad spectrum resistance to potato late blight. Proc. Natl. Acad. Sci. USA 2003, 100, 9128-9133. [CrossRef]

140. van der Vossen, E.; Sikkema, A.; Hekkert, B.; Gros, J.; Stevens, P.; Muskens, M.; Wouters, D.; Pereira, A.; Stiekema, W.; Allefs, S. An ancient R gene from the wild potato species Solanum bulbocastanum confers broad-spectrum resistance to Phytophthora infestans in cultivated potato and tomato. Plant J. 2003, 36, 867-882. [CrossRef] 
141. Oh, S.K.; Young, C.; Lee, M.; Oliva, R.; Bozkurt, T.O.; Cano, L.M.; Win, J.; Bos, J.I.; Liu, H.Y.; van Damme, M.; et al. In planta expression screens of Phytophthora infestans RXLR effectors reveal diverse phenotypes, including activation of the Solanum bulbocastanum disease resistance protein Rpi-blb2. Plant Cell 2009, 21, 2928-2947. [CrossRef] [PubMed]

142. van der Vossen, E.A.G.; Gros, J.; Sikkema, A.; Muskens, M.; Wouters, D.; Wolters, P.; Pereira, A.; Allefs, S. The Rpi-blb2 gene from Solanum bulbocastanum is an Mi-1 gene homolog conferring broad-spectrum late blight resistance in potato. Plant J. 2005, 44, 208-222. [CrossRef] [PubMed]

143. Bendahmane, A.; Querci, M.; Kanyuka, K.; Baulcombe, D.C. Agrobacterium transient expression system as a tool for the isolation of disease resistance genes: Application to the Rx2 locus in potato. Plant J. 2000, 21, 73-81. [CrossRef]

144. Brommonschenkel, S.H.; Frary, A.; Tanksley, S.D. The broad-spectrum tospovirus resistance gene Sw-5 of tomato is a homolog of the root-knot nematode resistance gene Mi. Mol. Plant Microbe Interact. 2000, 13, 1130-1138. [CrossRef] [PubMed]

145. Hallwass, M.; de Oliveira, A.S.; de Campos Dianese, E.; Lohuis, D.; Boiteux, L.S.; Inoue-Nagata, A.K.; Resende, R.O.; Kormelink, R. The Tomato spotted wilt virus cell-to-cell movement protein (NSM ) triggers a hypersensitive response in Sw-5-containing resistant tomato lines and in Nicotiana benthamiana transformed with the functional Sw-5b resistance gene copy. Mol. Plant Pathol. 2014, 15, 871-880. [CrossRef]

146. Calder, V.L.; Palukaitis, P. Nucleotide sequence analysis of the movement genes of resistance breaking strains of tomato mosaic virus. J. Gen. Virol. 1992, 73 Pt 1, 165-168. [CrossRef]

147. Lanfermeijer, F.C.; Warmink, J.; Hille, J. The products of the broken Tm-2 and the durable Tm-2(2) resistance genes from tomato differ in four amino acids. J. Exp. Bot. 2005, 56, 2925-2933. [CrossRef]

148. Lanfermeijer, F.C.; Dijkhuis, J.; Sturre, M.J.; de Haan, P.; Hille, J. Cloning and characterization of the durable tomato mosaic virus resistance gene Tm-2(2) from Lycopersicon esculentum. Plant Mol. Biol. 2003, 52, 1037-1049. [CrossRef]

149. Yoon, M.; Rikkerink, E.H.A. Rpa1 mediates an immune response to avrRpm $1_{\text {Psa }}$ and confers resistance against Pseudomonas syringae pv. actinidiae. Plant J. 2019. [CrossRef]

150. Bonas, U.; Conrads-Strauch, J.; Balbo, I. Resistance in tomato to Xanthomonas campestris pv vesicatoria is determined by alleles of the pepper-specific avirulence gene avrBs3. Mol. Gen. Genet. 1993, 238, 261-269. [CrossRef]

151. Kay, S.; Boch, J.; Bonas, U. Characterization of AvrBs3-like effectors from a Brassicaceae pathogen reveals virulence and avirulence activities and a protein with a novel repeat architecture. Mol. Plant Microbe Interact. 2005, 18, 838-848. [CrossRef] [PubMed]

152. Schornack, S.; Ballvora, A.; Gürlebeck, D.; Peart, J.; Baulcombe, D.; Ganal, M.; Baker, B.; Bonas, U.; Lahaye, T. The tomato resistance protein Bs4 is a predicted non-nuclear TIR-NB-LRR protein that mediates defense responses to severely truncated derivatives of AvrBs4 and overexpressed AvrBs3. Plant J. 2004, 37, 46-60. [CrossRef] [PubMed]

153. Paal, J.; Henselewski, H.; Muth, J.; Meksem, K.; Menéndez, C.M.; Salamini, F.; Ballvora, A.; Gebhardt, C. Molecular cloning of the potato Gro1-4 gene conferring resistance to pathotype Ro1 of the root cyst nematode Globodera rostochiensis, based on a candidate gene approach. Plant J. 2004, 38, 285-297. [CrossRef] [PubMed]

154. Erickson, F.L.; Holzberg, S.; Calderon-Urrea, A.; Handley, V.; Axtell, M.; Corr, C.; Baker, B. The helicase domain of the TMV replicase proteins induces the N-mediated defence response in tobacco. Plant J. 1999, 18, 67-75. [CrossRef]

155. Whitham, S.; Dinesh-Kumar, S.P.; Choi, D.; Hehl, R.; Corr, C.; Baker, B. The product of the tobacco mosaic virus resistance gene N: Similarity to toll and the interleukin-1 receptor. Cell 1994, 78, 1101-1115. [CrossRef]

156. Schultink, A.; Qi, T.; Lee, A.; Steinbrenner, A.D.; Staskawicz, B. Roq1 mediates recognition of the Xanthomonas and Pseudomonas effector proteins XopQ and HopQ1. Plant J. 2017, 92, 787-795. [CrossRef]

157. Thomma, B.P.; Nürnberger, T.; Joosten, M.H. Of PAMPs and effectors: The blurred PTI-ETI dichotomy. Plant Cell 2011, 23, 4-15. [CrossRef]

158. Navarro, L.; Zipfel, C.; Rowland, O.; Keller, I.; Robatzek, S.; Boller, T.; Jones, J.D. The transcriptional innate immune response to flg22. Interplay and overlap with Avr gene-dependent defense responses and bacterial pathogenesis. Plant Physiol. 2004, 135, 1113-1128. [CrossRef]

159. Tsuda, K.; Sato, M.; Stoddard, T.; Glazebrook, J.; Katagiri, F. Network properties of robust immunity in plants. PLoS Genet. 2009, 5, e1000772. [CrossRef] 
160. Kadota, Y.; Liebrand, T.W.H.; Goto, Y.; Sklenar, J.; Derbyshire, P.; Menke, F.L.H.; Torres, M.A.; Molina, A.; Zipfel, C.; Coaker, G.; et al. Quantitative phosphoproteomic analysis reveals common regulatory mechanisms between effector-and PAMP-triggered immunity in plants. New Phytol. 2019, 221, 2160-2175. [CrossRef]

161. Cook, D.E.; Mesarich, C.H.; Thomma, B.P. Understanding plant immunity as a surveillance system to detect invasion. Annu. Rev. Phytopathol. 2015, 53, 541-563. [CrossRef] [PubMed]

162. van der Burgh, A.M.; Joosten, M.H.A.J. Plant immunity: Thinking outside and inside the box. Trends Plant Sci. 2019, 24, 587-601. [CrossRef] [PubMed]

163. Leibman-Markus, M.; Pizarro, L.; Schuster, S.; Lin, Z.J.D.; Gershony, O.; Bar, M.; Coaker, G.; Avni, A. The intracellular nucleotide-binding leucine-rich repeat receptor (SINRC4a) enhances immune signalling elicited by extracellular perception. Plant Cell Environ. 2018, 41, 2313-2327. [CrossRef] [PubMed]

164. Mantelin, S.; Peng, H.C.; Li, B.; Atamian, H.S.; Takken, F.L.; Kaloshian, I. The receptor-like kinase SISERK1 is required for Mi-1-mediated resistance to potato aphids in tomato. Plant J. 2011, 67, 459-471. [CrossRef] [PubMed]

165. Gabriëls, S.H.; Vossen, J.H.; Ekengren, S.K.; van Ooijen, G.; Abd-El-Haliem, A.M.; van den Berg, G.C.; Rainey, D.Y.; Martin, G.B.; Takken, F.L.; de Wit, P.J.; et al. An NB-LRR protein required for HR signalling mediated by both extra-and intracellular resistance proteins. Plant J. 2007, 50, 14-28. [CrossRef] [PubMed]

166. Wu, C.H.; Belhaj, K.; Bozkurt, T.O.; Birk, M.S.; Kamoun, S. Helper NLR proteins NRC2a/b and NRC3 but not NRC1 are required for Pto-mediated cell death and resistance in Nicotiana benthamiana. New Phytol. 2016, 209, 1344-1352. [CrossRef]

167. Qi, Y.; Tsuda, K.; Glazebrook, J.; Katagiri, F. Physical association of pattern-triggered immunity (PTI) and effector-triggered immunity (ETI) immune receptors in Arabidopsis. Mol. Plant Pathol. 2011, 12, 702-708. [CrossRef]

168. Kud, J.; Wang, W.; Gross, R.; Fan, Y.; Huang, L.; Yuan, Y.; Gray, A.; Duarte, A.; Kuhl, J.C.; Caplan, A.; et al. The potato cyst nematode effector RHA1B is a ubiquitin ligase and uses two distinct mechanisms to suppress plant immune signaling. PLoS Pathog. 2019, 15, e1007720. [CrossRef]

169. Jacob, F.; Kracher, B.; Mine, A.; Seyfferth, C.; Blanvillain-Baufumé, S.; Parker, J.E.; Tsuda, K.; Schulze-Lefert, P.; Maekawa, T. A dominant-interfering camta3 mutation compromises primary transcriptional outputs mediated by both cell surface and intracellular immune receptors in Arabidopsis thaliana. New Phytol. 2018, 217, 1667-1680. [CrossRef]

170. Li, X.; Huang, L.; Zhang, Y.; Ouyang, Z.; Hong, Y.; Zhang, H.; Li, D.; Song, F. Tomato SR/CAMTA transcription factors SISR1 and SISR3L negatively regulate disease resistance response and SISR1L positively modulates drought stress tolerance. BMC Plant Biol. 2014, 14, 286. [CrossRef]

171. Albert, I.; Böhm, H.; Albert, M.; Feiler, C.E.; Imkampe, J.; Wallmeroth, N.; Brancato, C.; Raaymakers, T.M.; Oome, S.; Zhang, H.; et al. An RLP23-SOBIR1-BAK1 complex mediates NLP-triggered immunity. Nat. Plants 2015, 1, 15140. [CrossRef] [PubMed]

172. Boschi, F.; Schvartzman, C.; Murchio, S.; Ferreira, V.; Siri, M.I.; Galván, G.A.; Smoker, M.; Stransfeld, L.; Zipfel, C.; Vilaró, F.L.; et al. Enhanced bacterial wilt resistance in potato through expression of Arabidopsis EFR and introgression of quantitative resistance from Solanum commersonii. Front. Plant Sci. 2017, 8, 1642. [CrossRef] [PubMed]

173. Bouwmeester, K.; Han, M.; Blanco-Portales, R.; Song, W.; Weide, R.; Guo, L.Y.; van der Vossen, E.A.; Govers, F. The Arabidopsis lectin receptor kinase LecRK-I.9 enhances resistance to Phytophthora infestans in Solanaceous plants. Plant Biotechnol. J. 2014, 12, 10-16. [CrossRef] [PubMed]

174. Huang, P.Y.; Yeh, Y.H.; Liu, A.C.; Cheng, C.P.; Zimmerli, L. The Arabidopsis LecRK-VI.2 associates with the pattern-recognition receptor FLS2 and primes Nicotiana benthamiana pattern-triggered immunity. Plant J. 2014, 79, 243-255. [CrossRef]

175. Kunwar, S.; Iriarte, F.; Fan, Q.; Evaristo da Silva, E.; Ritchie, L.; Nguyen, N.S.; Freeman, J.H.; Stall, R.E.; Jones, J.B.; Minsavage, G.V.; et al. Transgenic expression of EFR and Bs2 genes for field management of bacterial wilt and bacterial spot of tomato. Phytopathology 2018, 108, 1402-1411. [CrossRef]

176. Lacombe, S.; Bangratz, M.; Vignols, F.; Brugidou, C. The rice yellow mottle virus P1 protein exhibits dual functions to suppress and activate gene silencing. Plant J. 2010, 61, 371-382. [CrossRef]

177. Hao, G.; Pitino, M.; Duan, Y.; Stover, E. Reduced susceptibility to Xanthomonas citri in transgenic citrus expressing the FLS2 receptor from Nicotiana benthamiana. Mol. Plant Microbe Interact. 2016, 29, $132-142$. [CrossRef] 
178. Jehle, A.K.; Lipschis, M.; Albert, M.; Fallahzadeh-Mamaghani, V.; Fürst, U.; Mueller, K.; Felix, G. The receptor-like protein ReMAX of Arabidopsis detects the microbe-associated molecular pattern eMax from Xanthomonas. Plant Cell 2013, 25, 2330-2340. [CrossRef]

179. Jehle, A.K.; Fürst, U.; Lipschis, M.; Albert, M.; Felix, G. Perception of the novel MAMP eMax from different Xanthomonas species requires the Arabidopsis receptor-like protein ReMAX and the receptor kinase SOBIR. Plant Signal. Behav. 2013, 8, e27408. [CrossRef]

180. Wu, J.; Reca, I.B.; Spinelli, F.; Lironi, D.; De Lorenzo, G.; Poltronieri, P.; Cervone, F.; Joosten, M.H.A.J.; Ferrari, S.; Brutus, A. An EFR-Cf-9 chimera confers enhanced resistance to bacterial pathogens by SOBIR1-and BAK1-dependent recognition of elf18. Mol. Plant Pathol. 2019, 20, 751-764. [CrossRef]

181. Hillmer, R.A.; Tsuda, K.; Rallapalli, G.; Asai, S.; Truman, W.; Papke, M.D.; Sakakibara, H.; Jones, J.D.G.; Myers, C.L.; Katagiri, F. The highly buffered Arabidopsis immune signaling network conceals the functions of its components. PLoS Genet. 2017, 13, e1006639. [CrossRef] [PubMed]

182. Mergner, J.; Frejno, M.; List, M.; Papacek, M.; Chen, X.; Chaudhary, A.; Samaras, P.; Richter, S.; Shikata, H.; Messerer, M.; et al. Mass-Spectrometry-based draft of the Arabidopsis proteome. Nature 2020, 409-414. [CrossRef] [PubMed]

183. Xu, G.; Greene, G.H.; Yoo, H.; Liu, L.; Marqués, J.; Motley, J.; Dong, X. Global translational reprogramming is a fundamental layer of immune regulation in plants. Nature 2017, 545, 487-490. [CrossRef] [PubMed]

184. Gu, Y.; Zavaliev, R.; Dong, X. Membrane trafficking in plant immunity. Mol. Plant 2017, 10, 1026-1034. [CrossRef]

185. Yang, F.; Kimberlin, A.N.; Elowsky, C.G.; Liu, Y.; Gonzalez-Solis, A.; Cahoon, E.B.; Alfano, J.R. A plant immune receptor degraded by selective autophagy. Mol. Plant 2019, 12, 113-123. [CrossRef]

186. Li, P.; Day, B. Battlefield cytoskeleton: Turning the tide on plant immunity. Mol. Plant Microbe Interact. 2019, 32, 25-34. [CrossRef]

187. Brooks, C.; Nekrasov, V.; Lippman, Z.B.; Van Eck, J. Efficient gene editing in tomato in the first generation using the clustered regularly interspaced short palindromic repeats/CRISPR-associated 9 system. Plant Physiol. 2014, 166, 1292-1297. [CrossRef]

188. Anfoka, G.; Moshe, A.; Fridman, L.; Amrani, L.; Rotem, O.; Kolot, M.; Zeidan, M.; Czosnek, H.; Gorovits, R. Tomato yellow leaf curl virus infection mitigates the heat stress response of plants grown at high temperatures. Sci. Rep. 2016, 6, 19715. [CrossRef]

189. Kwak, M.-J.; Kong, H.G.; Choi, K.; Kwon, S.-K.; Song, J.Y.; Lee, J.; Lee, P.A.; Choi, S.Y.; Seo, M.; Lee, H.J.; et al. Rhizosphere microbiome structure alters to enable wilt resistance in tomato. Nat. Biotechnol. 2018, 10. [CrossRef]

190. Vorholt, J.A.; Vogel, C.; Carlström, C.I.; Müller, D.B. Establishing causality: Opportunities of synthetic communities for plant microbiome research. Cell Host Microbe 2017, 22, 142-155. [CrossRef]

191. Roberts, R.; Mainiero, S.; Powell, A.F.; Liu, A.E.; Shi, K.; Hind, S.R.; Strickler, S.R.; Collmer, A.; Martin, G.B. Natural variation for unusual host responses and flagellin-mediated immunity against Pseudomonas syringae in genetically diverse tomato accessions. New Phytol. 2019, 223, 447-461. [CrossRef] [PubMed]

(C) 2020 by the authors. Licensee MDPI, Basel, Switzerland. This article is an open access article distributed under the terms and conditions of the Creative Commons Attribution (CC BY) license (http://creativecommons.org/licenses/by/4.0/). 